\title{
Quaternary foraminifera and mollusc assemblages on the southwestern African shelf
}

\author{
Eugene W. Bergh and John S. Compton
}

\begin{abstract}
The distribution of fossil foraminifera and mollusc assemblages is documented in vibracores recovered from the Namibian and South African shelf to determine changes in depositional environments during the Pleistocene-Holocene. An Uvigerina spp.dominated assemblage appeared in the early Pleistocene during the intensification of cold-water upwelling of the Benguela Upwelling System (BUS). The palaeoenvironment experienced periodic maximal shoaling after the onset of major glacial periods since the mid-Pleistocene transition (ca. $900 \mathrm{ka}$ ) as indicated by the appearance of shallow water benthic foraminifera, dominated by Ammonia japonica and Elphidium spp., replacing Uvigerina spp.-dominated assemblage. The mollusc assemblages also change with Carditella spp., Lucinoma capensis, Nassarius vinctus, Dosinia lupinus, and Tellina analogica becoming the dominant species on the shelf. The benthic foraminifera and molluscs indicate greater productivity over the middle and outer shelf as the BUS intensified and high-amplitude sea-level fluctuations reworked and condensed sediment packages on the shelf. The planktic foraminifera show similarities to other upwelling regions globally, with Globigerina bulloides the dominant species. Warm water species such as Globigerinoides ruber, Globorotalia menardii, and Trilobatus sacculifer occur as minor to trace components attributed to the episodic inflow of warm water currents north and south of the region.
\end{abstract}

Eugene Bergh. Research Department, Iziko South African Museum, Cape Town 8000, South Africa; Marine Research Institute and Department of Geological Sciences, University of Cape Town, Rondebosch 7701, South Africa. eugene.bergh@alumni.uct.ac.za John Compton. Marine Research Institute and Department of Geological Sciences, University of Cape Town, Rondebosch 7701, South Africa. john.compton@uct.ac.za

Keywords: Pleistocene; Holocene; Namibia; South Africa; Benguela Upwelling System; mid-Pleistocene transition; sea level

Submission: 6 August 2019. Acceptance: 4 June 2020.

Bergh, Eugene W. and Compton, John S. 2020. Quaternary foraminifera and mollusc assemblages on the southwestern African shelf. Palaeontologia Electronica, 23(2):a27. https://doi.org/10.26879/1018 palaeo-electronica.org/content/2020/3062-offshore-namibian-foraminifera

Copyright: June 2020 Paleontological Society.

This is an open access article distributed under the terms of Attribution-NonCommercial-ShareAlike 4.0 International (CC BY-NC-SA 4.0), which permits users to copy and redistribute the material in any medium or format, provided it is not used for commercial purposes and the original author and source are credited, with indications if any changes are made.

creativecommons.org/licenses/by-nc-sa/4.0/ 


\section{INTRODUCTION}

The sediments underlying the Benguela Upwelling System (BUS) are enriched in organic carbon (Pedersen and Calvert, 1990; Shannon and Nelson, 1996; Mollenhauer et al., 2002), with sediment deposition on the continental margin during the Pleistocene being influenced by high-amplitude sea-level fluctuations during glacial-interglacial cycles (Diester-Haass et al., 1992; Mollenhauer et al., 2002; Compton and Wiltshire, 2009). Namibian shelf sediments are phosphorite-rich (Compton and Bergh, 2016), and the high productivity of the system has contributed to a high abundance of fossils (foraminifera, molluscs, ostracods, fish remains) on the continental shelf, which is important in palaeoenvironmental and geologic studies. How the microfossil and fossil (mainly molluscs) assemblages on the Namibian shelf have been influenced by Pleistocene sea-level fluctuations has previously not been investigated and can provide a biostratigraphic reference to one of the world's most productive upwelling regions focused over the shelf. Previous studies on surface grab samples (Martin, 1974, 1981; Lowry, 1987; Giraudeau, 1993; Schmidt-Sinns, 2008) focussed on the occurrences of species around the Namibian and South African coast, but, because limited to surface samples, did not allow for palaeoceanographic reconstructions of the BUS. Exploration for phosphorite deposits on the shelf has provided a large number of vibracores and owing to the highly condensed deposits, these cores provide, for the first time, a stratigraphic record from the Neogene to Recent.

Much of the research on the Pleistocene history of the BUS has focused on slope sediments along the southwestern margin of Africa owing to Deep Sea Drilling Program (DSDP) Leg 75, sites 362, 530-532 (Hay et al., 1984), and Ocean Drilling Program (ODP) Leg 175, sites 1080 to 1087 (Wefer et al., 1998). The cores retrieved from these expeditions allowed for the interpretation of palaeoceanographic and assemblage changes over time. These slope sediments have been studied to determine sediment deposition (Diester-Haass and Rothe, 1987; Robinson et al., 2002), upwelling intensity (Baumann and Freitag, 2004) and productivity (Schmiedl and Mackensen, 1997; Marlow et al., 2000; Rau et al., 2002; Jahn et al., 2003; Baumann and Freitag, 2004; Lazarus et al., 2008) along the southwestern continental margin of southern Africa.

Foraminifera from cores and sediments from the western continental shelf of southern Africa allow for the biostratigraphy and interpretation of palaeoenvironments along the shelf. South African shelf foraminifera have provided information on the stratigraphy of sediments and their associated palaeoenvironments from the Miocene to Holocene (Dale and McMillan, 1999; Compton et al., 2002, 2004; Franceschini and Compton, 2004). More recent work involving foraminifera on the Namibian shelf included the occurrence of foraminifera in anoxic environments along the Namibian margin (Leiter and Altenbach, 2010) and the biostratigraphy of shelf sediments (Compton and Bergh, 2016; Bergh et al., 2018). Compton and Bergh (2016) provided detailed analyses on the stratigraphy, formation, and geochemistry of the phosphorite deposits on the Namibian shelf and included species lists of foraminifera and molluscs to support the strontium isotope stratigraphy and age model of the sediments.

Using new data from the Namibian continental shelf and previous studies from the western South African shelf, this paper aims to identify Quaternary foraminiferal and molluscan assemblages to document how they relate to Pleistocene sea-level fluctuations. In particular, these assemblages provide a record of palaeoenvironmental shifts, such as substrate, bathymetry, and bottom water conditions associated with changes in sea level, corresponding to the intensification of the BUS during the Quaternary. The biostratigraphy and palaeoenvironmental reconstructions are important in phosphorite exploration and in documenting how taxa respond to long-term palaeoceanographic changes in a major coastal upwelling region.

\section{GEOLOGIC AND OCEANOGRAPHIC SETTING}

The study area is situated offshore between Walvis Bay and Lüderitz on the central Namibian continental shelf to the northern Namibian continental shelf, south of the Kunene River mouth (Figure 1). The Namibian margin formed during the rifting of Gondwana during the Cretaceous period. The continental shelf extends to $400 \mathrm{~m}$ and is divided into an inner ( 0 to $130 \mathrm{~m}$ ), middle (130 to $200 \mathrm{~m}$ ), and outer shelf (200 to $500 \mathrm{~m}$ ) (Rogers, 1977). The Walvis Ridge extends from the northern Namibian continental margin to the Mid-Atlantic Ridge to the west and acts as a barrier to deepwater flow (Berger et al., 1998).

Precambrian basement rocks are exposed on the rocky shoreline and inner shelf. Neogene and Quaternary sediments unconformably overlay Cretaceous and early Cenozoic strata (Bremner, 1977). Neogene sediments and strata on the shelf 


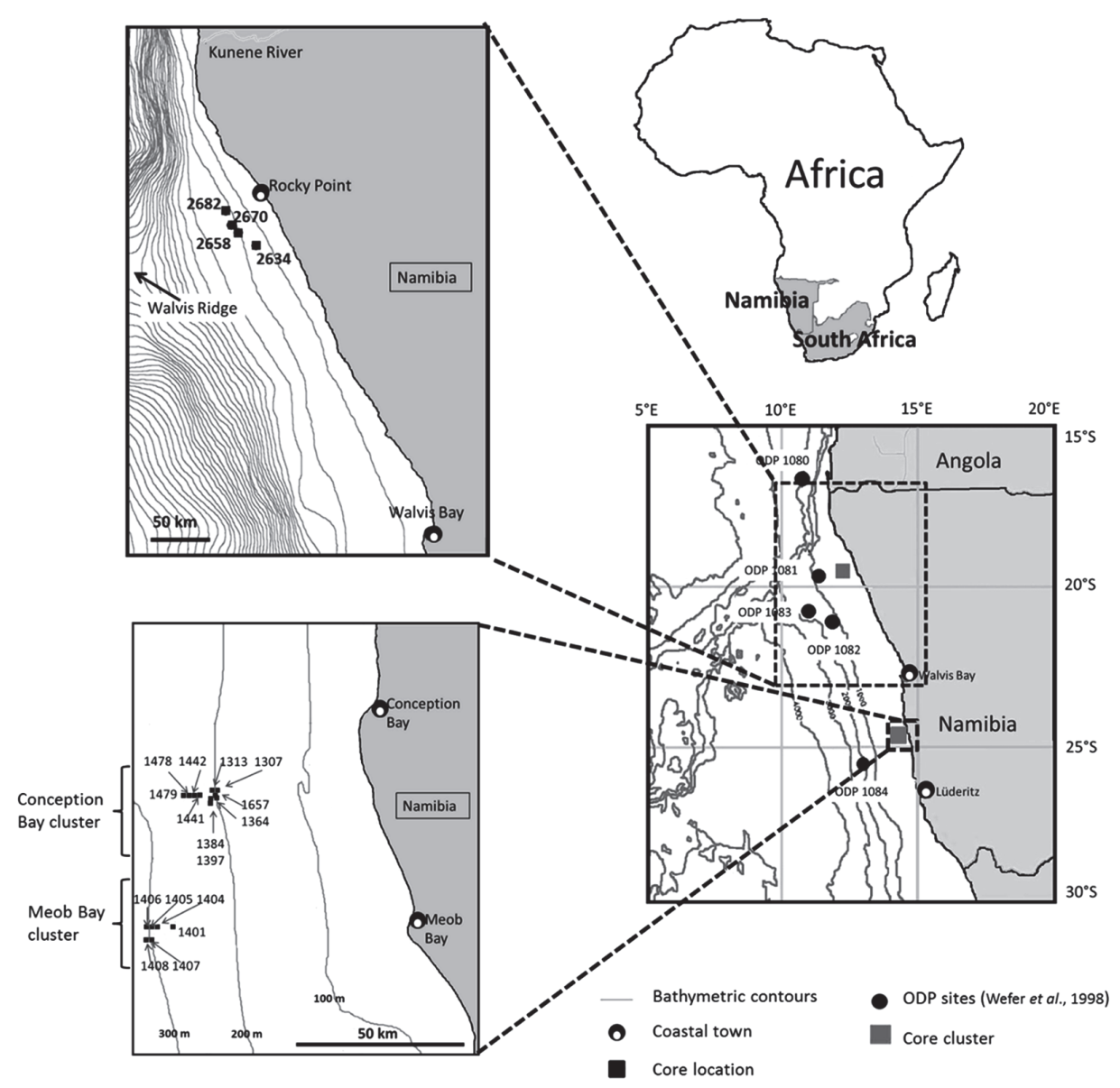

FIGURE 1. Outline of Namibia and South Africa with the location of the cores studied. The intervals for the bathymetric lines in the upper left map are 100 m (based on maps provided by Minemakers Australia Pty. Ltd.).

are condensed as a result of non-deposition, erosion, eustatic sea level lowering, episodic tectonic uplift, and the intensification of aridity in the continental interior (Dingle et al., 1983; Wigley and Compton, 2006; Bergh et al., 2018). Relict phosphorite deposits are exposed on the middle to outer shelf between 130 and $400 \mathrm{~m}$ water depth (Compton and Bergh, 2016). The $2 \mathrm{~m}$ condensed Pliocene-Pleistocene phosphorite-rich deposits on the shelf are contrasted by nannofossil and diatomaceous mud deposits 400-600 m thick (Meyers et al., 1998) on the upper slope (Compton and Bergh, 2016). A diatomaceous mud belt dated to the Holocene extends from south of the Kunene River mouth to Walvis Bay and is largely confined to the inner shelf (Bremner, 1977).

The BUS along the Namibian margin is highly productive with cold, upwelled, nutrient-rich waters influencing sedimentation along the continental shelf (Lutjeharms and Stockton, 1987). The colder waters of the BUS are influenced by subpolar deep water masses and upwelled by southeast trade winds that blow alongshore (Shannon and Nelson, 1996). The Benguela Current (BC) forms the eastern limb of the South Atlantic gyre and is distinct from the BUS. The cold upwelled waters of the BC are bounded by warmer currents to the north and south. To the north, the BC meets the warmer Angola Current at the Angola-Benguela Front (ABF) (Moroshkin et al., 1970) and to the south the $B C$ meets the Agulhas Current, which originates in the warmer Indian Ocean. The Agulhas Current flows westwards south of South Africa before it retroflects back eastwards south of the BUS. Some of the warmer waters from the Agulhas Current can flow into the BUS, transporting warmer water foraminifera taxa into the area (Rau et al., 2002).

\section{MATERIALS AND METHODS}

Twenty vibracores less than $2 \mathrm{~m}$ in length from the continental shelf between the Walvis BayLüderitz (16 cores) and northern Namibian shelf (4 
cores) (Figure 1) were retrieved by Minemakers Pty. Ltd. in 2008 and 2012, respectively. The cores were selected based on stratigraphic and faunal lists documented in Compton and Bergh (2016). The cores were logged and split into working and archive halves. The Walvis Bay-Lüderitz cores consist of two clusters, namely the Conception and Meob Bay clusters (Figure 1). The cores were sampled along depth intervals where contacts were clear and every 10 to $20 \mathrm{~cm}$ where units were greater than $10 \mathrm{~cm}$ thick. Samples selected at contacts allowed for environmental changes to be tested for during different time intervals. The samples were washed, sieved, and split into $<63 \mu \mathrm{m}$ (mud), $63 \mu \mathrm{m}$ to $2 \mathrm{~mm}$ (sand) and $>2 \mathrm{~mm}$ (gravel) fractions. The sand fractions were put in an ultrasonic cleaner for up to 1 minute to ensure all particles were disaggregated. Five cores, based on the completeness of their stratigraphy and length of record, were selected from the shallow middle (core 1307 - $199 \mathrm{~m}$; core $1441-223 \mathrm{~m}$ ), shallow outer (core $1401-244 \mathrm{~m}$; core $1479-245 \mathrm{~m}$ ), and deep outer shelf (core $1406-309 \mathrm{~m}$ ).

Foraminifera (from the separated sand fractions) and molluscs (from the separated gravel fractions) were identified in all 20 cores. Foraminifera, other biogenic and mineral (detrital and authigenic) components in the five selected cores were counted under a stereomicroscope to at least 300 individuals per sample to determine the dominant taxa (highest relative abundance) on which palaeoenvironmental interpretations rely. Foraminifera were counted in representative splits if individuals accounted for more than 300 in the samples. Where foraminifera were less abundant, all individuals were counted in the entire sample. The mean relative abundances of the biogenic and mineral components, reported as percentages, were calculated from these counts.

Whole mollusc shells and fragments were counted to determine the relative abundances. Intact bivalve shells, and where complete shells were present and matched another shell, were counted as one individual. Complete intact bivalve shells and complete gastropod shells may give an indication of minimal transport. Fragments were identified based on a part of a shell that is broken or where multiple fragments were present. Only fragments that could be attributed to certain species were assigned to that species.

The core lithology is presented in Compton and Bergh (2016) and reveals an overall coarsening upward succession (Figure 2). Cores 1405, 1408 , and 1406 consist of a basal olive-green mud unit grading into coarser sandy units with biogenic and authigenic grains towards the top of the cores. Six units were identified in the Walvis Bay-Lüderitz cores (Compton and Bergh, 2016). Units 6 and 5 are olive green mud units with abundant fragmented foraminifera dated to the Pliocene. Unit 4 is a black to leached brown pelletal phosphorite sandy unit (Figure 3 ). Unit 3 is a slightly shelly sandy unit, whereas unit 2 is a shelly sandy unit that contains abundant shell material and whole shells. Gravel components (large bone fragments, phosphorite pebbles and concretionary phosphorite nodules) result in units 5 to 2 having coarser grain sizes in some cores. Unit 1 is a sandy gravel unit containing abundant shell fragments, whole mollusc shells and foraminifera.

Representative microfossils were picked for scanning electron microscope (SEM) imaging. The microfossils were mounted onto black adhesive carbon tabs and coated with a thin layer of GoldPalladium using a BIO-RAD SEM coating system before SEM images were taken with a JEOL JSM5200 scanning microscope at Iziko Museums in Cape Town.

The age model for the cores was based on a combination of strontium isotope stratigraphy (SIS) and biostragraphic planktic foraminiferal indicator species (Compton and Bergh, 2016; Bergh et al., 2018). The different sand and gravel components (foraminifera, pelletal phosphorite grains, concretionary phosphorite pebbles, fragmented fish bones, teeth, scales, and mollusc shell fragments) were previously picked from bulk gravel and sandsized material and run for strontium isotope analysis (Compton and Bergh, 2016). Planktic foraminiferal indicator species were identified based on Kennett and Srinivasan (1983) and Bolli et al. (1985).

Statistical analyses were performed using the PAlaeontologicalSTatistics (PAST) data analysis package (Hammer et al., 2001). Hierarchical cluster analysis was used to estimate similarities in species composition in samples to determine subassemblages within the core stratigraphy with Ward's method and Euclidean distance applied.

\section{RESULTS}

\section{Stratigraphy and Sedimentology}

The sediment of the olive-green muds contains abundant foraminifera (55-98\%) with minor amounts of echinoid spines, shell fragments, fish bone material, ostracods, and pelletal phosphorite 

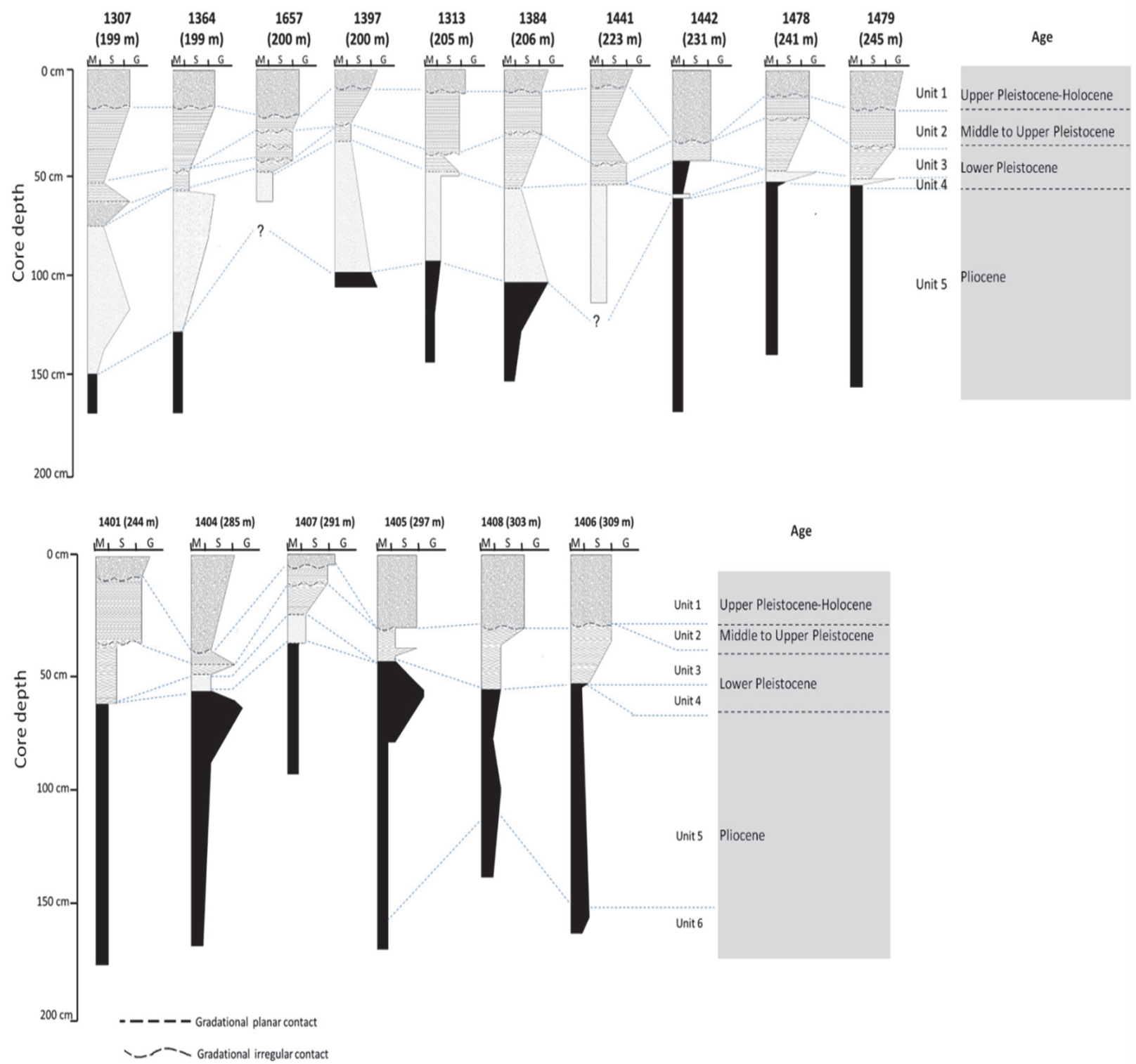

FIGURE 2. Stratigraphy of the Conception and Meob Bay cores. The depositional ages and units are defined by Compton and Bergh (2016). Unit $6=$ reworked foram layer; unit $5=$ brown to olive-green mud unit; unit $4=$ pelletal phosphorite sandy layer; unit 3 = slightly shelly layer; unit 2 = shelly sandy layer; unit 1 = shelly gravel layer (Compton and Bergh, 2016).

in intercalated lenses towards the top of the base unit.

With the exception of the mud unit, the pelletal phosphorite content decreases up-core (Figure 3) with a maximum abundance (mean of $88.5 \%$ ) in the sandy units (unit 4). Shell contents are highest (mean $=12.3 \%)$ in the shelly gravel unit (unit 1). Foraminifera are most abundant (mean $=85.4 \%$ ) in the sand fractions of the olive-green mud unit (unit 5). Above unit 4 the foraminiferal abundance increases upwards and reaches a mean abundance of $12.3 \%$ in unit 1 .

Bone material in the sand fractions comprises a small amount and only attains its highest abundance $($ mean $=5.8 \%)$ in the sandy units (unit 4 ). Other components remain negligible $(<1 \%)$ throughout the successions of the cores and include echinoid spines, fish otoliths, sponge spicules, ostracods, and bryozoan fragments. 


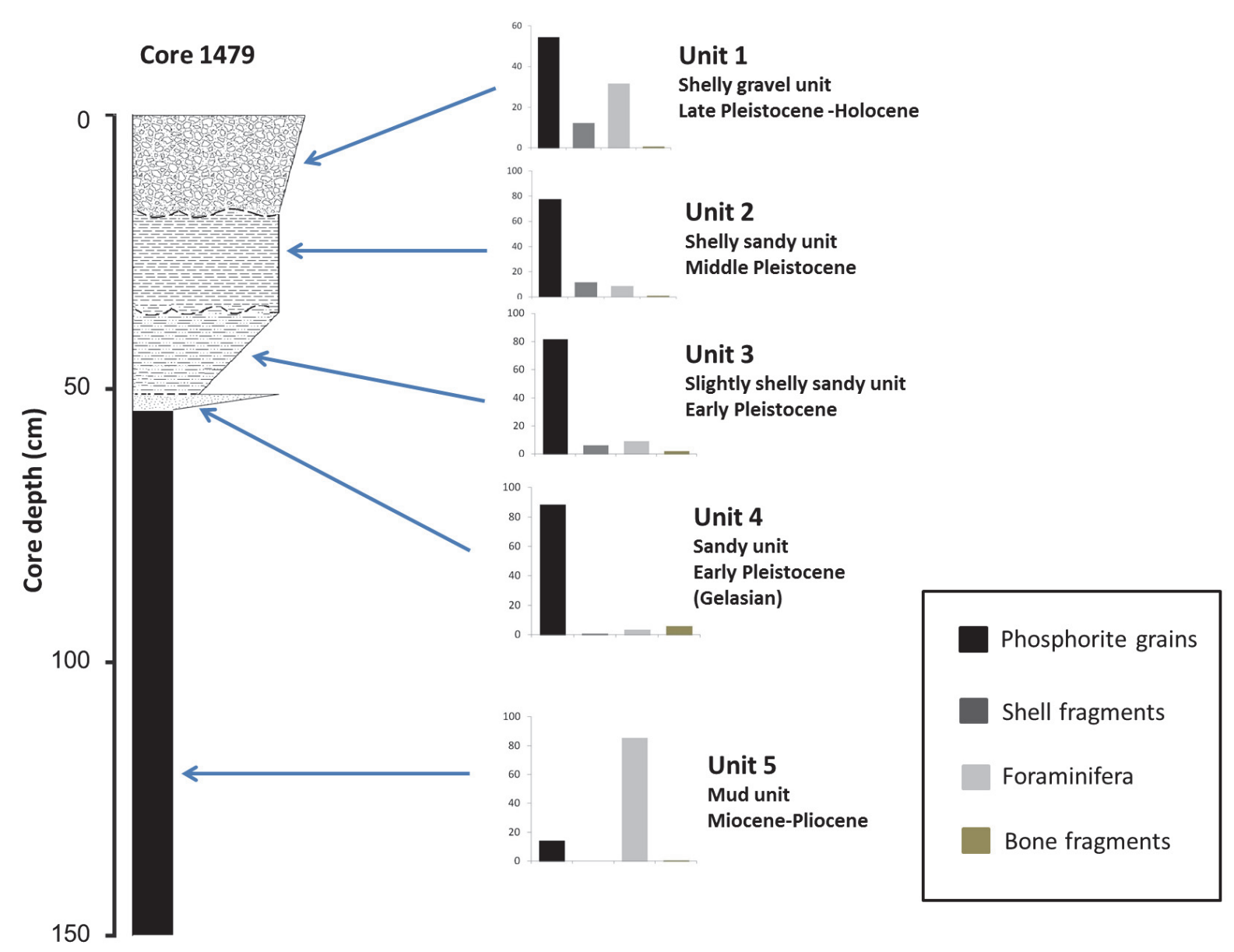

FIGURE 3. Mean relative abundance, represented by column charts, of the major components within the complete sand fractions of core 1479 .

\section{Planktic Foraminifera}

The most abundant planktic foraminiferal species preserved in all the units is Globigerina bulloides $(\min .=46.9 \% ;$ max. $=100 \%)$ decreasing in abundance (Figure 4 ) towards the less shelly units. The maximum percentage of $G$. bulloides preserved in the sediments was encountered in one sample of unit 3 in core 1479. Planktic species Globorotalia (Globoconella) inflata and Globigerinoides ruber (white) $(<2 \%)$ have higher abundances in unit 3 relative to units 2 and 1, whereas Neogloboquadrina incompta recorded similar abundances across all the units with the highest abundance in unit 3. Other planktic species with low relative abundances $(<1 \%)$ in both the central Namibian and northern Namibian shelf include Neogloboquadrina dutertrei and Globigerinella siphonifera. Orbulina universa recorded low numbers $(<1 \%)$ on the central Namibian shelf, but higher relative abundances on the northern Namibian shelf $(<47 \%)$.

\section{Benthic Foraminifera}

The pelletal phosphorite sandy unit 4 with more than $80 \%$ pelletal phosphorite sand content generally does not contain foraminifera (Figure 3). Very few foraminifera in the sediments are agglutinated $(<1 \%$ abundance) and miliolids accounted for $<1 \%$ of the foraminiferal assemblages in the shelly sandy units. The classification of biofacies on foraminiferal assemblages corresponds to sedimentological units of the cores.

Unit 3 recorded higher proportions of Uvigerina peregrina with Cassidulina laevigata and Bolivina spathulata (syn. Brizalina spathulata) increasing towards the contact between units 3 and 2. Unit 2 still had abundant Uvigerina spp. but their relative abundances decreased towards the con- 


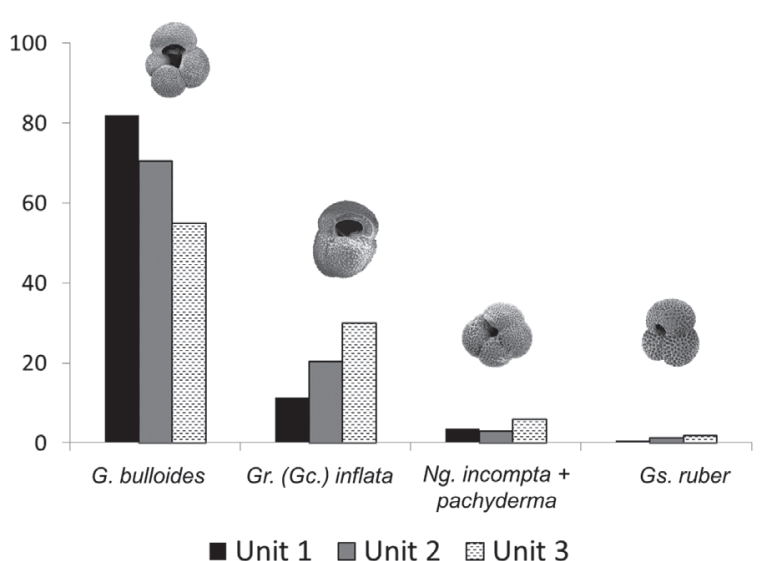

FIGURE 4. Mean relative abundance of planktic species preserved across the three units of the Walvis BayLüderitz cores.

tact between units 2 and 1 , and $B$. spathulata maintained similar abundances (Figure 5). Unit 2 also recorded higher Elphidium advenum abundances. Unit 1 is characterised by the dominance of Ammonia japonica and higher relative $E$. advenum abundances.

The dominant species in the upper units of the cores (unit 1 in Walvis Bay-Lüderitz) are $A$. japonica and Elphidium spp. with Cassidulina laevigata recording similar relative abundances between the two areas. Relative abundances for Cibicidoides lobatulus (syn. Lobatula lobatula) are higher $(>10 \%)$ in the less gravelly units of the northern Namibian cores south of the Kunene River mouth compared to cores in the Walvis Bay-Lüderitz area. In the less gravelly units of the northern cores, Nonion boueanus recorded abundances of $>40 \%$. In the deepest core south of the Kunene River mouth occurrences of Globobulimina turgida reach relative abundances $>50 \%$.

Cluster analysis divided the units containing abundant Uvigerina spp., B. Spathulata, and $A$. japonica into three main fossil assemblages based on their relative abundances. These assemblages are (1) Uvigerina spp., (2) Uvigerina spp.-A. japonica-B. Spathulata, and (3) A. japonica (Figure 6).

\section{Molluscs}

The 25 analysed samples from the five selected cores yielded a total of 86 whole or nearwhole bivalve shells and 110 gastropod shells, which could be assigned to 13 bivalve taxonomic groups (genus and species level) and five gastropod taxonomic groups (genus and species level). The upper portions of the northern Namibian as well as the Walvis Bay-Lüderitz cores reveal similar dominant mollusc species. The most abundant whole bivalve shells are Carditella sp. and Lucinoma capensis in unit 2 of the Walvis Bay-Lüderitz cores (Figures 7-8). Lucinoma capensis is the most abundant fragmented shell. The dominant gastropod species throughout all the cores are Nassarius vinctus in whole and fragmented forms with Turritella declivis only observed in unit 2. Marginella spp. are observed in both units of the Walvis BayLüderitz cores. In unit 2, Dosinia lupinus and Tellina analogica form a minor component $(<10 \%)$ in whole and fragmented forms, but increase in relative abundance to become dominant species in unit 1. The bivalve species Carditella sp. and Nucula nucleus mostly occur as whole shells while Lucinoma capensis mostly occurs as fragments in unit 1.

The bivalve Pecten spp. was the only species (in fragmented form; Figure 9) to have been observed in the olive-green mud unit of the northern Namibian cores. The dominant gastropod in the overlying gravelly sandy phosphorite units of the northern Namibian cores is Nassarius vinctus (Figure 10) throughout, with Volutacorbis lutosa and Comitas saldanhae present, but in lower numbers. The dominant bivalve species in the layers below the upper $10 \mathrm{~cm}$ of the northern Namibian cores are Lucinoma capensis and Tellina analogica (whole and fragmented). The bivalve species Dosinia lupinus, Carditella sp., and Nuculana bicuspidata are among the major bivalve components as whole shells, but decrease in the fragmented fraction. In the upper $10 \mathrm{~cm}$ of the cores Dosinia lupinus and Tellina analogica are the dominant bivalves in whole shell form, whereas specimens of Lucinoma capensis are more abundant in the fragmented fraction.

\section{DISCUSSION}

\section{Biogeography}

The most abundant planktic foraminiferal species preserved at the middle to outer shelf depths along the Namibian shelf during the Quaternary are G. bulloides and Gr. (Gc.) inflata (Figure 11). Low abundances of Gs. ruber were recorded for the northern Namibian shelf and the Walvis BayLüderitz region. Along the northern Namibian shelf $\mathrm{Ng}$. incompta (previously Ng. pachyderma dextral) also occurs in relatively high abundances, specifically in the less shelly units. Previous studies from onshore deposits (Dale and McMillan, 1999; McMillan, 1990a, 1990b) reported few to no planktic tests where Pleistocene environments were 


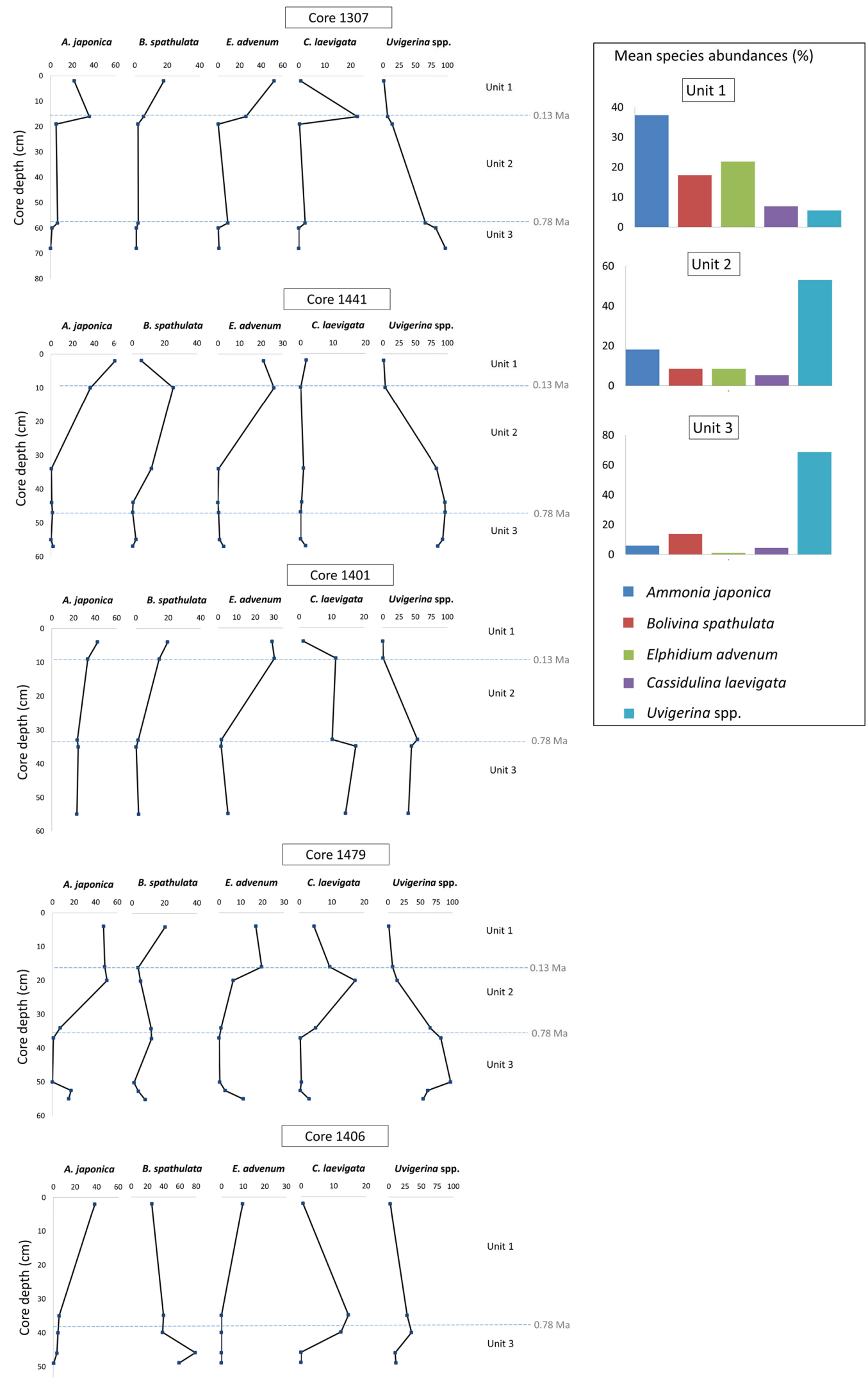

FIGURE 5. Relative abundances (\%) of benthic foraminifera in the shelly sandy units 1-3. Mean relative abundances of the major taxa in each unit over all the cores in which the foraminifera species counted are indicated upper right. 


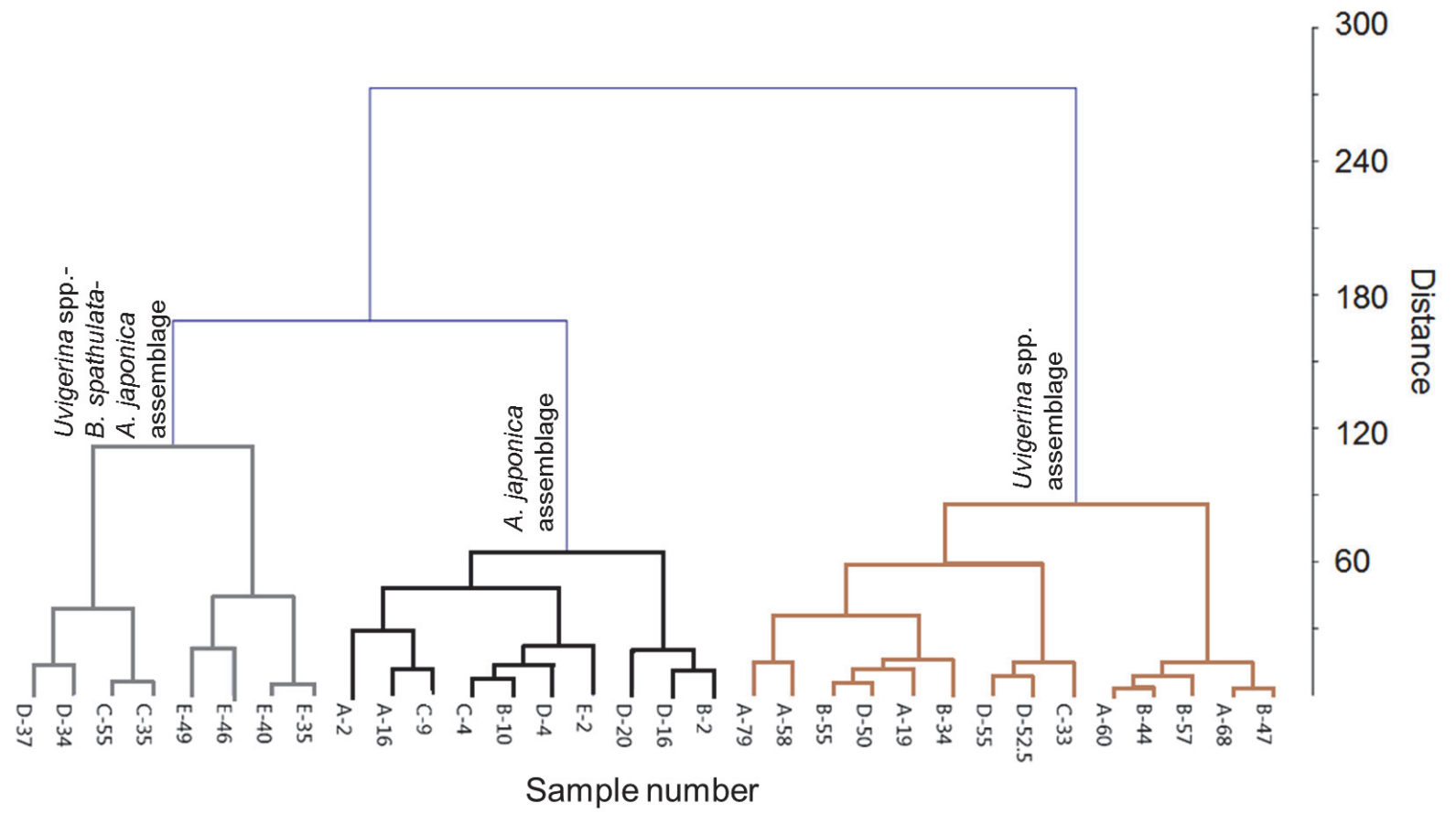

FIGURE 6. Dendrogram from a hierarchical cluster analysis (Ward's method) based on Euclidean distance as similarity index to determine sub-assemblages. The sample number refers to the core and core depth (in $\mathrm{cm}$ ). $A=\mathrm{core} 1307$; $B=$ core $1441 ; C=$ core $1401 ; D=$ core $1479 ; E=$ core 1406

shallower than the outer shelf deposits $(<300 \mathrm{~m})$. This marks a progression of increased species diversity and abundances from shallow water inner to middle shelf environments preserved in onshore highstand deposits to the outer shelf and slope.

Many of the benthic foraminiferal species recorded in this study have wide distributions stretching from the northern Namibian shelf to the south and east coasts of South Africa. These taxa are commonly associated with cosmopolitan species (Lowry, 1987; and references therein). Two samples collected by Schmiedl (1995) at water depths of $173 \mathrm{~m}$ (GeoB 1021, southern Angolan shelf) and $250 \mathrm{~m}$ (GeoB 1013, central Angolan shelf) reveal assemblages with similar taxa. The benthic species Bulimina marginata, Cassidulina laevigata, Lobatula lobatula, Globobulimina turgida, and Uvigerina peregrina were recorded at both sites by Schmiedl (1995), while Bulimina gibba and Elphidium advenum were found to occur only at the shallower site. Schmidt-Sinns (2008) also found the distribution of taxa on the inner shelf to be widespread between Cape Town and southern Angola. The species Quinqueloculina seminula, Rectuvigerina nicoli, Bulimina elongata, Bulimina gibba, Cancris auriculus, Cassidulina laevigata, Uvigerina peregrina, and Elphidium advenum recorded in this study were also found by
Schmidt-Sinns (2008) to occur at inner shelf depths (Figures 12, 13, 14).

Foraminifera recorded in surface grab sediments (Lowry, 1987) have also been recorded in Pleistocene sediments and outcrops (Dale and McMillan, 1999; Compton et al., 2002, 2004; Franceschini and Compton, 2004; Compton and Bergh, 2016; this study) and on the Holocene mud belt of South Africa (Dale and McMillan, 1998). McMillan (1990a) recorded similar benthic taxa from borehole and outcrop samples of the Upper Algoa Group along the south coast of South Africa which include Ammonia spp., Elphidium spp., Nonion boueanus, Cibicidoides lobatulus, Quinqueloculina cf. seminula, Cancris auriculus, Bulimina gibba, and Brizalina spathulata.

Most of the foraminifera species on the outer shelf occurring in Pleistocene, Holocene, and surface grab samples first appeared in the sediment record during the Pliocene-Pleistocene transition. These assemblages are generally absent in older deposits, corresponding with the timing of the period in which the BUS intensified along the margin. Franceschini and Compton (2004), however, dated first occurrences of Cibicidoides lobatulus, Ammonia spp. and Elphidium crispum from shallow water environments to the late Miocene/Pliocene using SIS. This is in contrast to outer shelf deposits 


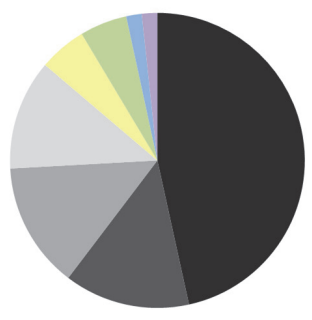

Bivalves unit 1 whole shells

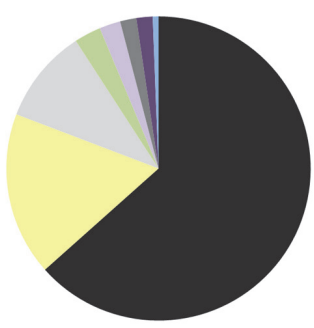

Bivalves unit 1 shell fragments

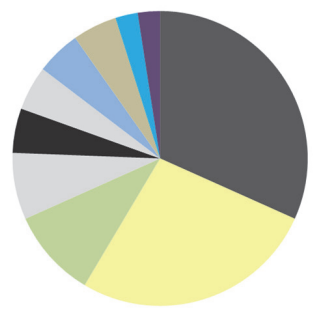

Bivalves unit 2 whole shells

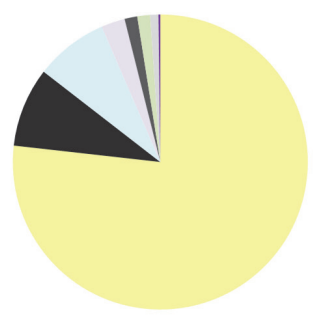

Bivalves unit 2 shell fragments

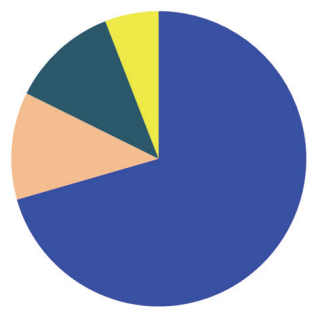

Gastropods unit 1 whole shells

Bivalves

$\square$ Dosinialupinus

- Carditella spp.

$\square$ Nuculanucleus

$\square$ Tellina analogica

Lucinomacapensis

Cardium sp.

Hiatella arctica

Anomiasp.

Limopsis chunii

Nuculanabicuspidata

Ostrea sp.

Pecten sp.

\section{Gastropods}

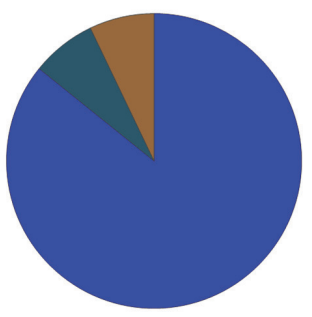

- Nassarius vinctus

Volutacorbis lutosa

Turritella declivis

Comitas saldanhae

Marginella spp.

Gastropods unit 2 whole shells

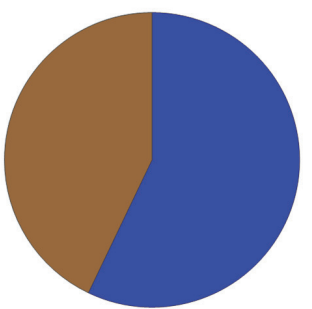

Gastropods unit 2 shell fragments

FIGURE 7. Mean relative abundances of mollusc (bivalves on the left and gastropods on the right) shells in the Walvis Bay-Lüderitz cores.

of Namibia as the Miocene-Pliocene assemblages contain deeper water species (Bergh et al., 2018) and do not record similar species observed in the onshore South African marine deposits as noted by Franceschini and Compton (2004). These species may have existed at inner shelf water depths not sampled in this study.

The major taxa between the Namibian shelf and the South African western shelf (Compton et al., 2004) are similar with minor species and diver- sity changes likely attributed to small-scale ecosystem heterogeneities linked to substrate, seasonality, and periodicity of coastal upwelling, in addition to differences in organic matter fluxes and dissolved oxygen contents in bottom waters (Schmiedl et al., 1997). For example, SchmidtSinns (2008) found bottom water dissolved oxygen to be the major driver behind the differences between faunal compositions of the Southern Benguela and Northern Benguela regions. 


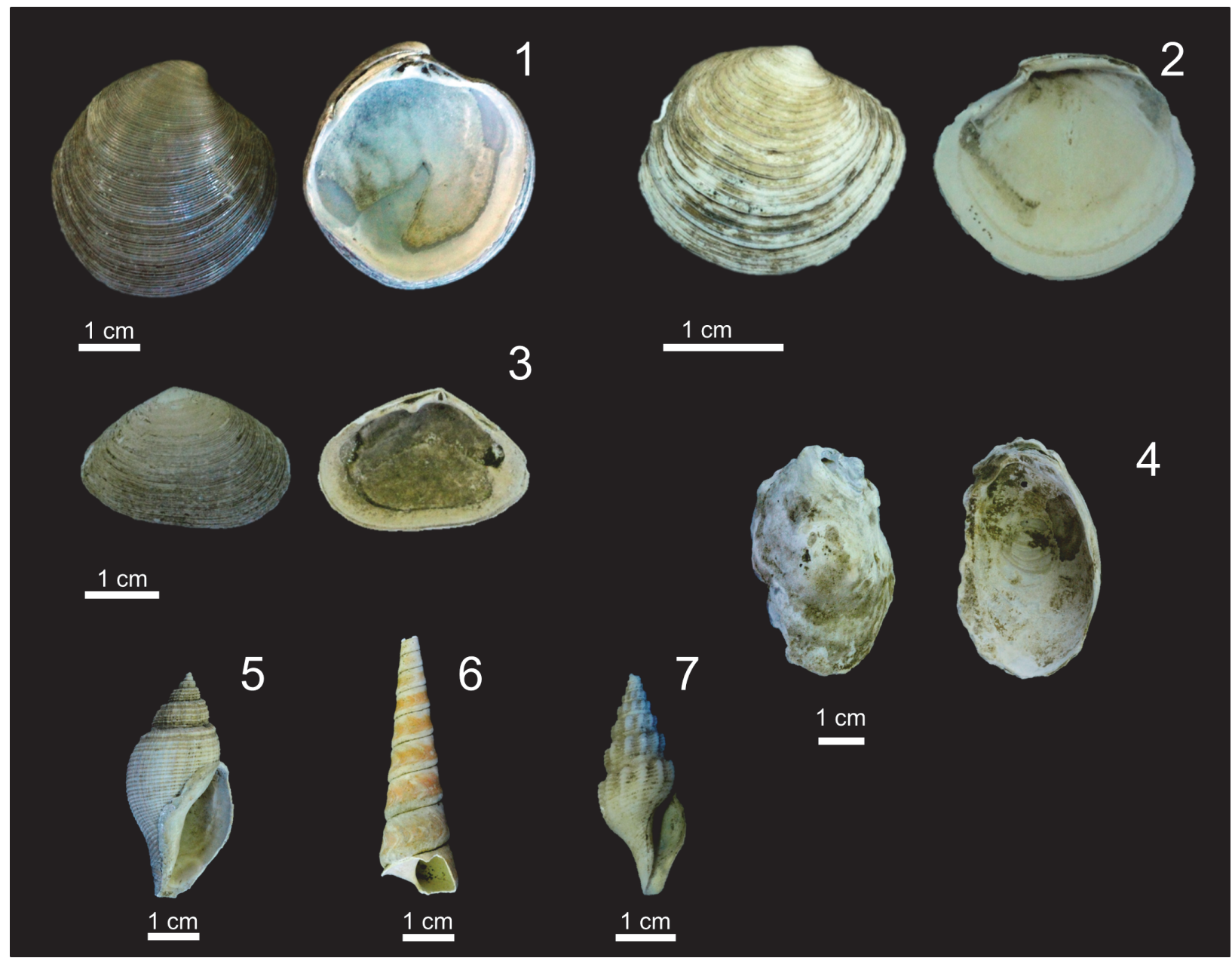

FIGURE 8. Mollusc shells from the gravel fraction of the uppermost 2 units of the Walvis Bay-Lüderitz cores. 1. Dosinia lupinus (Linnaeus, 1758) (core 1407, 0-4 cm sampling interval); 2. Lucinoma capensis (Jaeckel and Thiele, 1931) (core 1397, 0-4 cm); 3. Tellina (Moerella) analogica Sowerby III, 1904 (core 1478, 8-12 cm); 4. Ostrea sp. (core 1657, 0-4 cm); 5. Nassarius vinctus (Marrat, 1877) (core 1407, 0-4 cm); 6. Turritella declivis Adams and Reeve, 1850 (core 1657, 20-24 cm); 7. Comitas saldanhae (Barnard, 1958) (core 1307, 0-4 cm).

\section{Foraminifera on the Namibian Shelf Compared to Slope Foraminifera}

The three major planktic species recorded in this study, G. bulloides, Gr. (Gc.) inflata and $\mathrm{Ng}$. incompta, are also the dominant species recorded along the upper slope (Wefer et al., 1998) (Table 1) and continue to be the dominant species today (Giraudeau, 1993). Modern distributions of $G$. bulloides show higher relative abundances along the shelf of Namibia whereas Gr. (Gc.) inflata increases towards the slope off northern Namibia and western South Africa. Higher relative abundances of $\mathrm{Ng}$. incompta also occur along the Namibian margin (Giraudeau, 1993).

Pleistocene foraminifera along the Namibian continental shelf are distinct from those along the slope (Figure 15). Present-day foraminifera on the slope are also distinct from outer shelf foraminifera (below $400 \mathrm{~m}$ on the broad continental shelf of southwestern Africa) and are strongly influenced by the Oxygen Minimum Zone (OMZ) and related biogeochemical gradients (Schmiedl et al., 1997). The dominant slope species during the late Pleistocene off Namibia were Bulimina spp. and Uvigerina hispidocostata. Shelf species are largely absent in slope sediments. Trace to minor abundances $(<1$ to $10 \%$ ) of $A$. japonica and Hyalinea balthica were reported for the Plio-Pleistocene along the slope of Namibia and western South Africa (Wefer et al., 1998). On the northern Namibian slope very low abundances (generally $<1 \%$ ) of Quinqueloculina spp. were reported for the Pleistocene (Berger et al., 1998). Relative abundances of Quinqueloculina seminula were also found to be very low $(<1 \%)$ in 


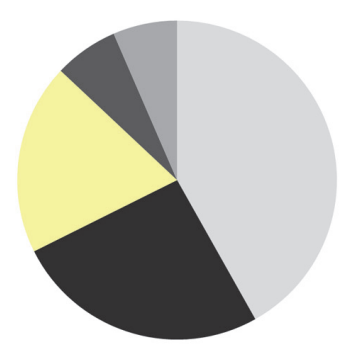

Bivalves top layer whole shells

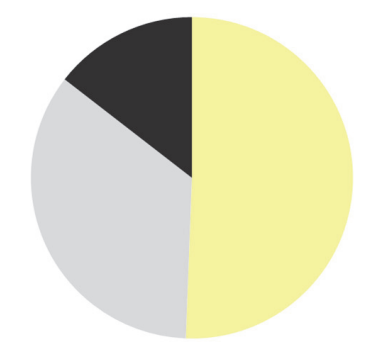

Bivalves top layer shell fragments

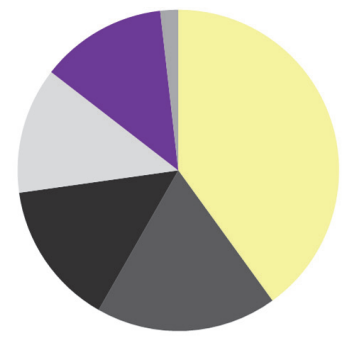

Bivalves whole shells

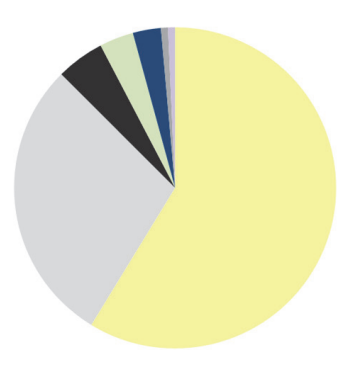

Bivalves shell fragments

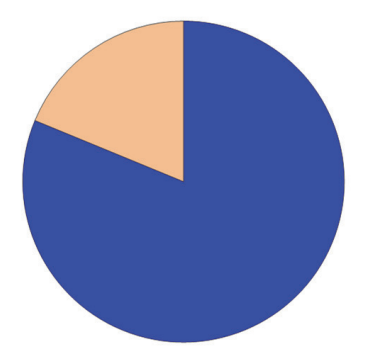

Gastropods top layer whole shells

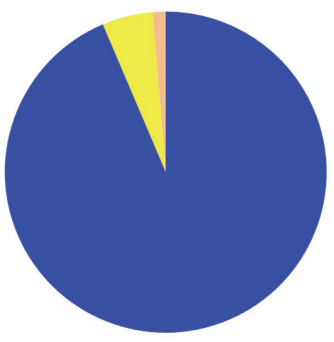

Gastropods whole shells

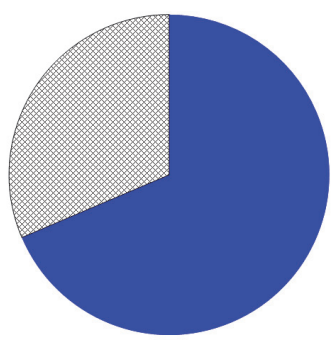

Gastropods shell fragments
Bivalves

— Dosinialupinus

Carditella spp.

Nucula nucleus

Tellina analogica

Lucinomacapensis

Nuculana bicuspidata

$\square$ Ostreasp.

Pecten sp.

Mytilus sp.

Gastropods

Nassarius vinctus

Volutacorbis lutosa

Comitas saldanhae

Marginella spp.

Unidentified fragments

FIGURE 9. Mean relative abundances of mollusc shells (bivalves on the left and gastropods on the right) in the northern Namibian cores.

this study area. The other species present in slope sediments that are also present in Pleistocene shelf sediments is Cassidulina laevigata, but this species has a broader bathymetric range and has been documented to occur at slope depths (Schmiedl et al., 1997). Cassidulina laevigata is a minor component of the slope assemblages during the early Pliocene becoming a major component during the late Pliocene and Pleistocene. Slope sediments also indicate Bulimina marginata to be a minor component $(<10 \%$ relative abundance) of the assemblages along Namibia and South Africa during the Plio-Pleistocene. 


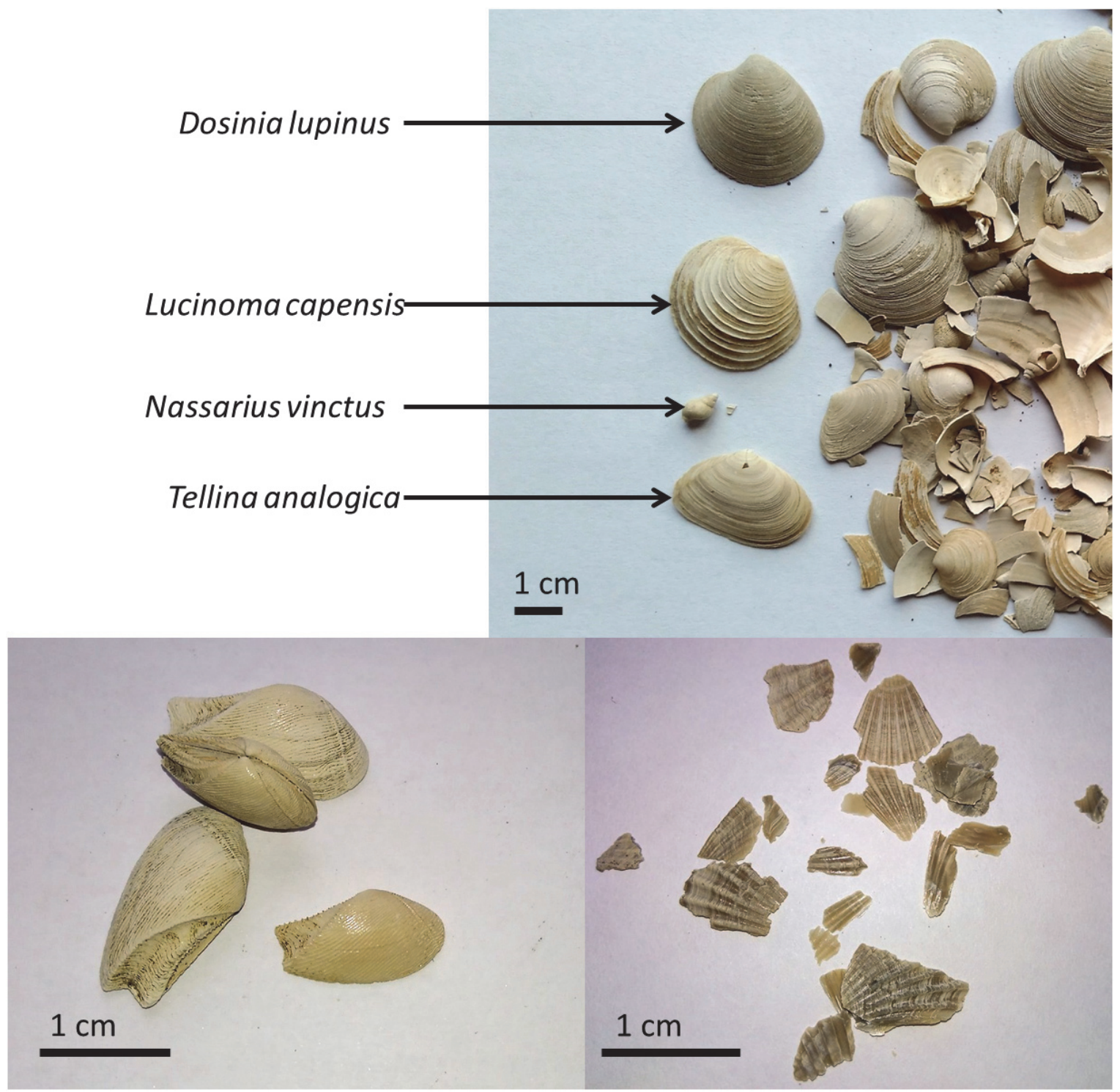

FIGURE 10. Whole and fragmented shells (top) (core 2658, 10-15 cm sampling interval), Nuculana bicuspidata (bottom left) shells including articulated valves (core 2634, 78-85 cm) and Pecten spp. fragments (bottom right) (core 2658, $88-90 \mathrm{~cm}$ ) from the northern Namibian cores.

The differences in shelf and slope assemblages, as well as the differences in sediment composition, imply that very few foraminiferal tests and other sand-sized grains are transported from the shelf to the slope. The flow velocities of most bottom currents observed along the margin are too weak to suspend coarser sandy material from the shelf to the slope (Shannon and Nelson, 1996) and will winnow away muddy sediment and leave sandsized material, including foraminifera on the shelf. Bottom currents are stronger during glacial sealevel lowstands. Compton and Wiltshire (2009) noted the transport and deposition of quartz and glauconite grains from the outermost shelf to the slope of western South Africa during glacial lowstands. The fluctuating strength of the internal tides, bottom currents, turbidity flows (from rare seismic activity) and flow velocities during the Pleistocene thus account for the transport and deposition of the few shelf species documented in slope sediments in minor to trace amounts.

\section{Foraminifera and Molluscs Indicate Cooling, Shoaling, and Increased Productivity along the Margin}

Subtropical sea surface conditions indicated by warm water species Gs. ruber, T. Sacculifer, and $T$. immaturus during the middle Miocene 


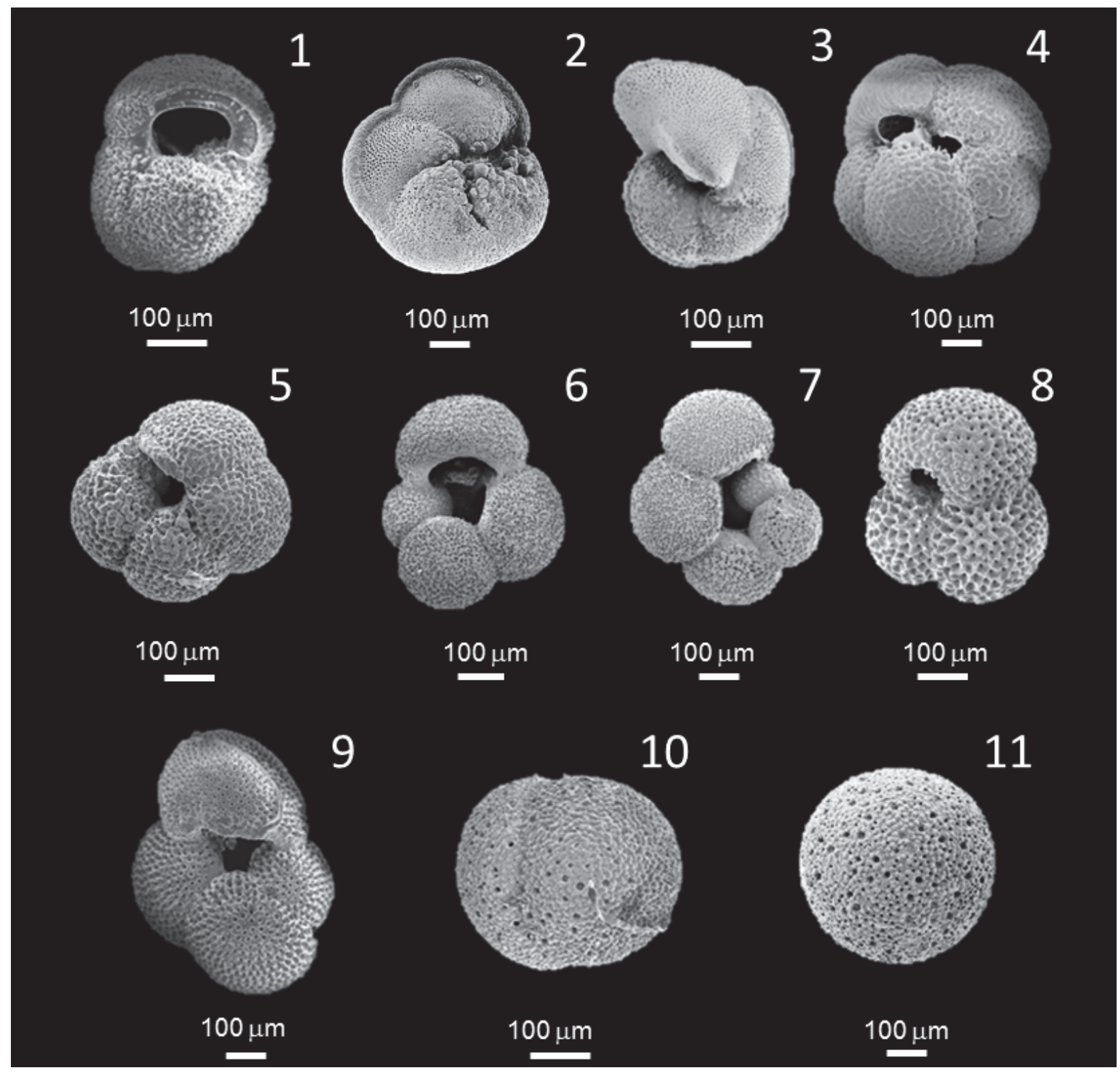

FIGURE 11. Planktic foraminifera from the Namibian outer shelf with primary apertural views visible. 1. Globorotalia (Globoconella) inflata (d'Orbigny, 1839b) (core 2670, $98 \mathrm{~cm}$ ); 2. Globorotalia menardii (Parker, Jones and Brady, 1865) (core 2670, $23 \mathrm{~cm}$ ); 3. Globorotalia truncatulinoides (d'Orbigny, 1839b) (core 2670, $23 \mathrm{~cm}$ ); 4. Neogloboquadrina dutertrei (d'Orbigny, 1839a) (core 2670, $43 \mathrm{~cm}$ ); 5. Neogloboquadrina incompta (Cifelli, 1961) (core 2670, $85 \mathrm{~cm}$ ); $6 \mathrm{Globi-}$ gerina bulloides d'Orbigny, 1826 (core 2670, $85 \mathrm{~cm}$ ); 7. Globigerinella siphonifera (d'Orbigny, 1839b) (core 2670,33 $\mathrm{cm}$ ); 8. Globigerinoides ruber white (d'Orbigny, 1839a) (core 2670, $13 \mathrm{~cm}$ ); 9. Trilobatus sacculifer (Brady, 1877) (core 2670, $63 \mathrm{~cm}$ ); 10. Orbulina bilobata (d'Orbigny, 1846) (core 2670, $3 \mathrm{~cm}$ ); 11. Orbulina universa d'Orbigny, 1839a (core 2670, $33 \mathrm{~cm})$.

(Bergh et al., 2018) cooled during the PliocenePleistocene transition when $G$. bulloides and $\mathrm{Gr}$. (Gc.) inflata became the dominant planktic taxa. Abundant $G$. bulloides has been recorded in upper Pliocene sediments along the northeastern margin of South America, also associated with upwelling and cooling (Ibaraki, 1997). The Pliocene sedi- ments off Walvis Bay-Lüderitz contain a mixture of deep benthic and warm subtropical planktic foraminifera. Together with G. bulloides and Gr. (Gc.) inflata the Pliocene foraminifera indicate changing conditions associated with the initiation of the BUS during the Miocene/Pliocene along the Namibian margin (Compton and Bergh, 2016). The faunal 


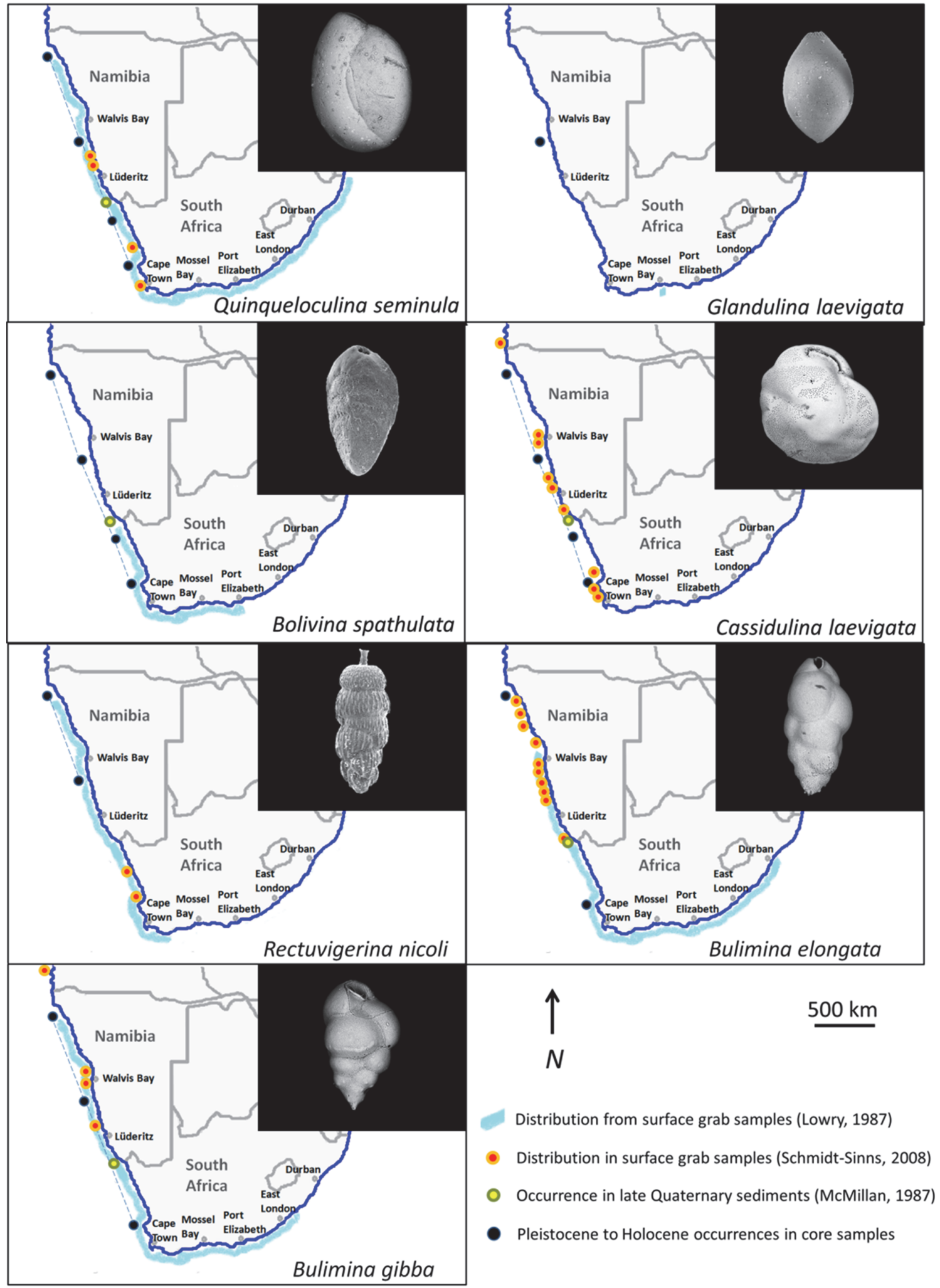

FIGURE 12. Distribution maps of benthic foraminifera occurring in Namibian and western South African outer shelf (blue shading = Lowry, 1987; black dots = Compton et al., 2002, 2004 and this study), lower to middle upper Quaternary sediments (green-yellow dots = McMillan, 1987) and inner shelf surface grab sediments (red-yellow dots = Schmidt-Sinns, 2008). Samples from McMillan (1987), Compton et al. (2002, 2004) and this study represent Pleistocene-aged foraminifera and samples from Lowry (1987) and Schmidt-Sinns (2008) are from surface grab sediments. 


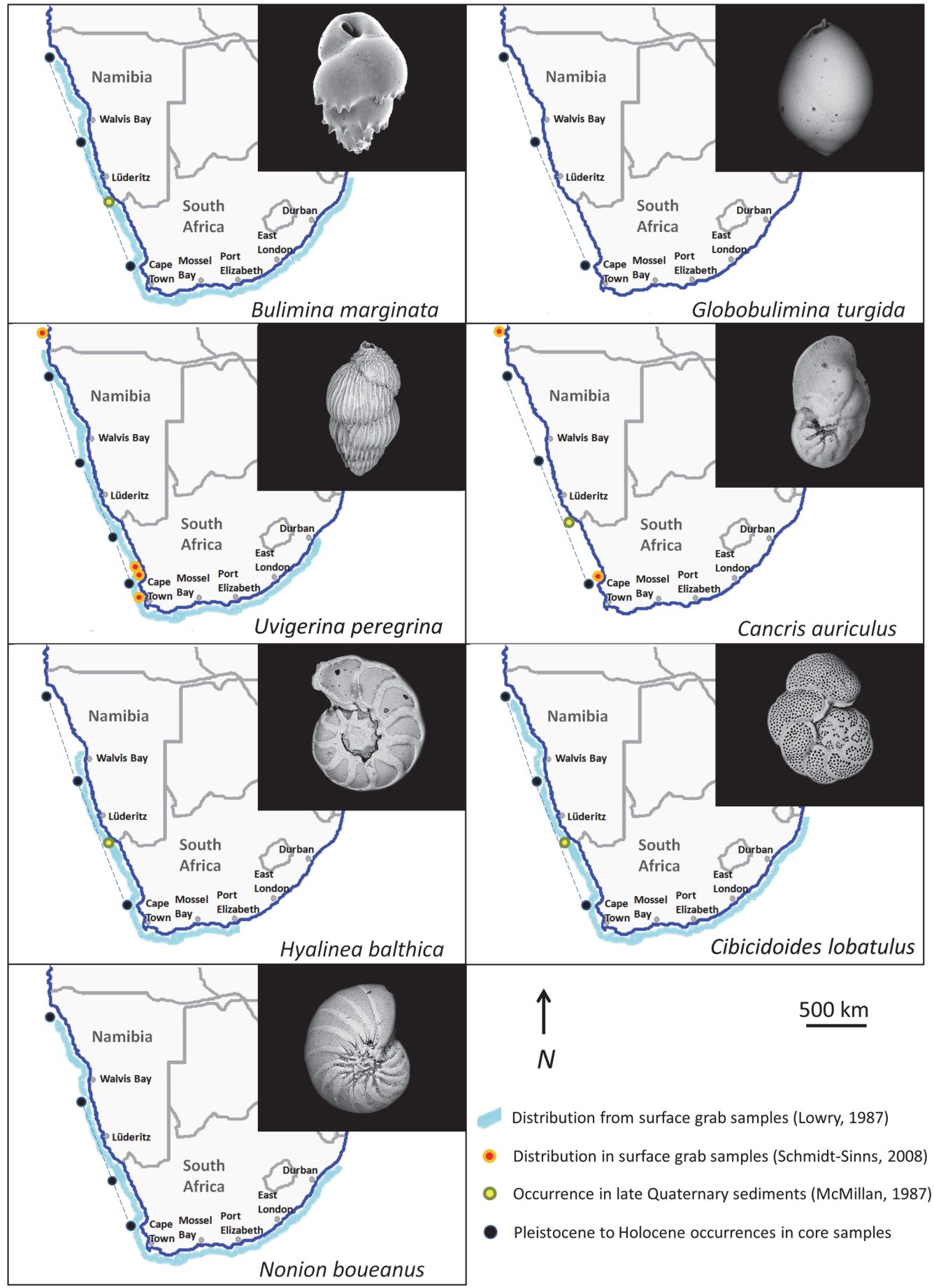

FIGURE 13. Distribution maps of benthic foraminifera occurring in Namibian and western South African outer shelf (blue shading = Lowry, 1987; black dots = Compton et al., 2002, 2004 and this study), lower to middle upper Quaternary sediments (green-yellow dots $=$ McMillan, 1987) and inner shelf surface grab sediments (red-yellow dots = Schmidt-Sinns, 2008). Samples from McMillan (1987), Compton et al. (2002, 2004) and this study represent Pleistocene-aged foraminifera and samples from Lowry (1987) and Schmidt-Sinns (2008) are from surface grab sediments. 


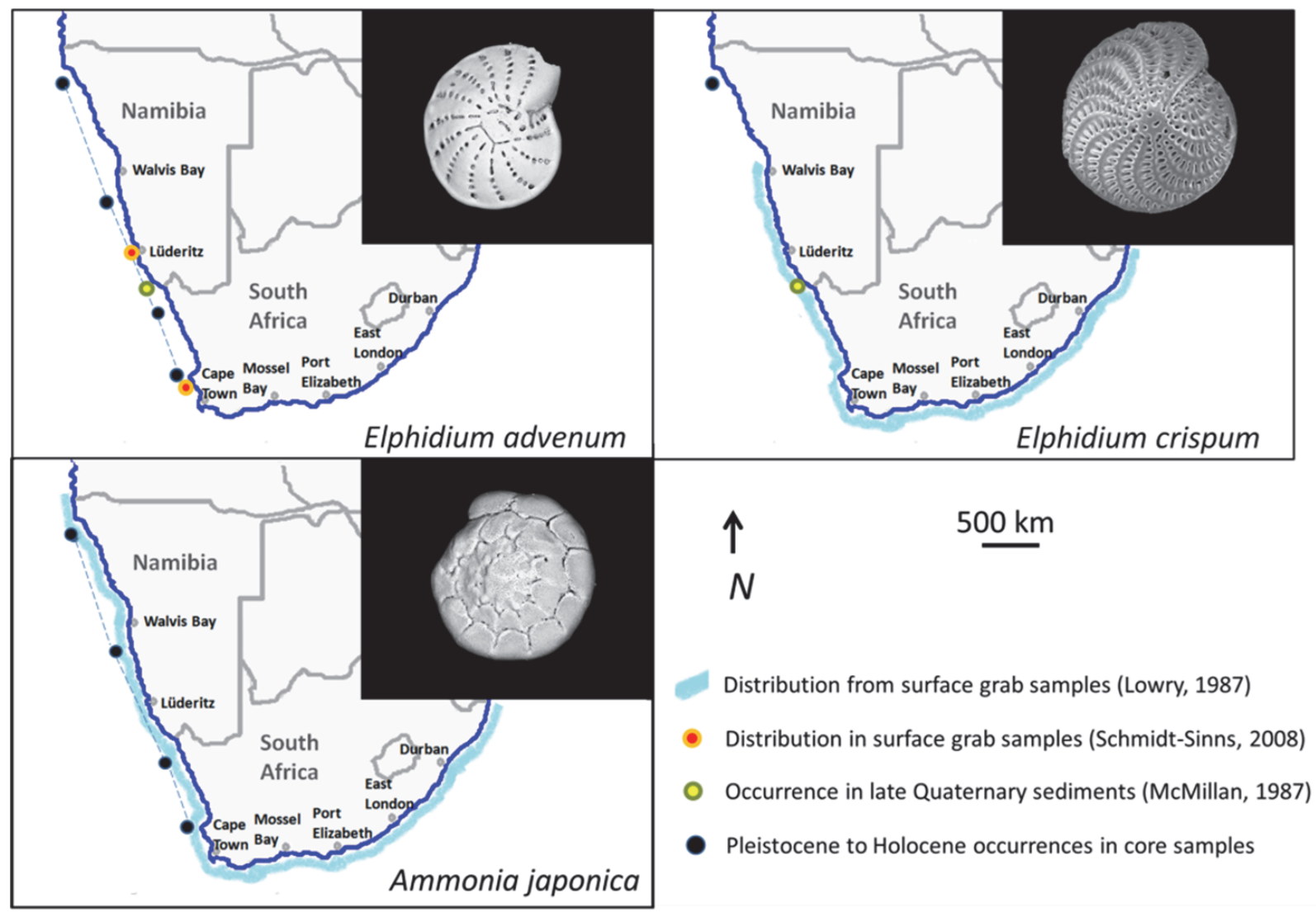

FIGURE 14. Distribution maps of benthic foraminifera occurring in Namibian and western South African outer shelf (blue shading = Lowry, 1987; black dots = Compton et al., 2002, 2004 and this study), lower to middle upper Quaternary sediments (green-yellow dots = McMillan, 1987) and inner shelf surface grab sediments (red-yellow dots = Schmidt-Sinns, 2008). Samples from McMillan (1987), Compton et al. (2002, 2004) and this study represent Pleistocene-aged foraminifera and samples from Lowry (1987) and Schmidt-Sinns (2008) are from surface grab sediments.

TABLE 1. Shelf (Compton et al., 2002, 2004; this study) and slope planktic foraminifera (Giraudeau, 1993; Wefer et al., 1998) along the western margin of Namibia and South Africa.

\begin{tabular}{lcclcc}
\hline \multicolumn{1}{c}{ Planktic species } & Slope & Shelf & Planktic species & Slope & Shelf \\
\hline Beella digitata & $\mathrm{x}$ & & Globorotalia hirsuta & $\mathrm{x}$ & \\
Globigerina bulloides & $\mathrm{x}$ & $\mathrm{x}$ & Globorotalia inflata & $\mathrm{x}$ & $\mathrm{x}$ \\
Globigerina falconensis & $\mathrm{x}$ & & Globorotalia menardii & $\mathrm{x}$ & $\mathrm{x}$ \\
Globigerina quinqueloba & $\mathrm{x}$ & & Globorotalia scitula & $\mathrm{x}$ & \\
Globigerina umbilicata & $\mathrm{x}$ & & Globorotaloides hexagona & $\mathrm{x}$ & \\
Globigerinella siphonifera & $\mathrm{x}$ & $\mathrm{x}$ & Hastigerina siphonifera & $\mathrm{x}$ & \\
Globigerinita glutinata & $\mathrm{x}$ & & Neogloboquadrina dutertrei & $\mathrm{x}$ & \\
Globigerinoides ruber & $\mathrm{x}$ & $\mathrm{x}$ & Neogloboquadrina pachyderma & $\mathrm{x}$ & $\mathrm{x}$ \\
Globigerinoides truncatulinoides & $\mathrm{x}$ & $\mathrm{x}$ & Orbulina universa & $\mathrm{x}$ & $\mathrm{x}$ \\
Globorotalia crassaformis & $\mathrm{x}$ & & Trilobatus sacculifer & $\mathrm{x}$ & $\mathrm{x}$ \\
\hline
\end{tabular}




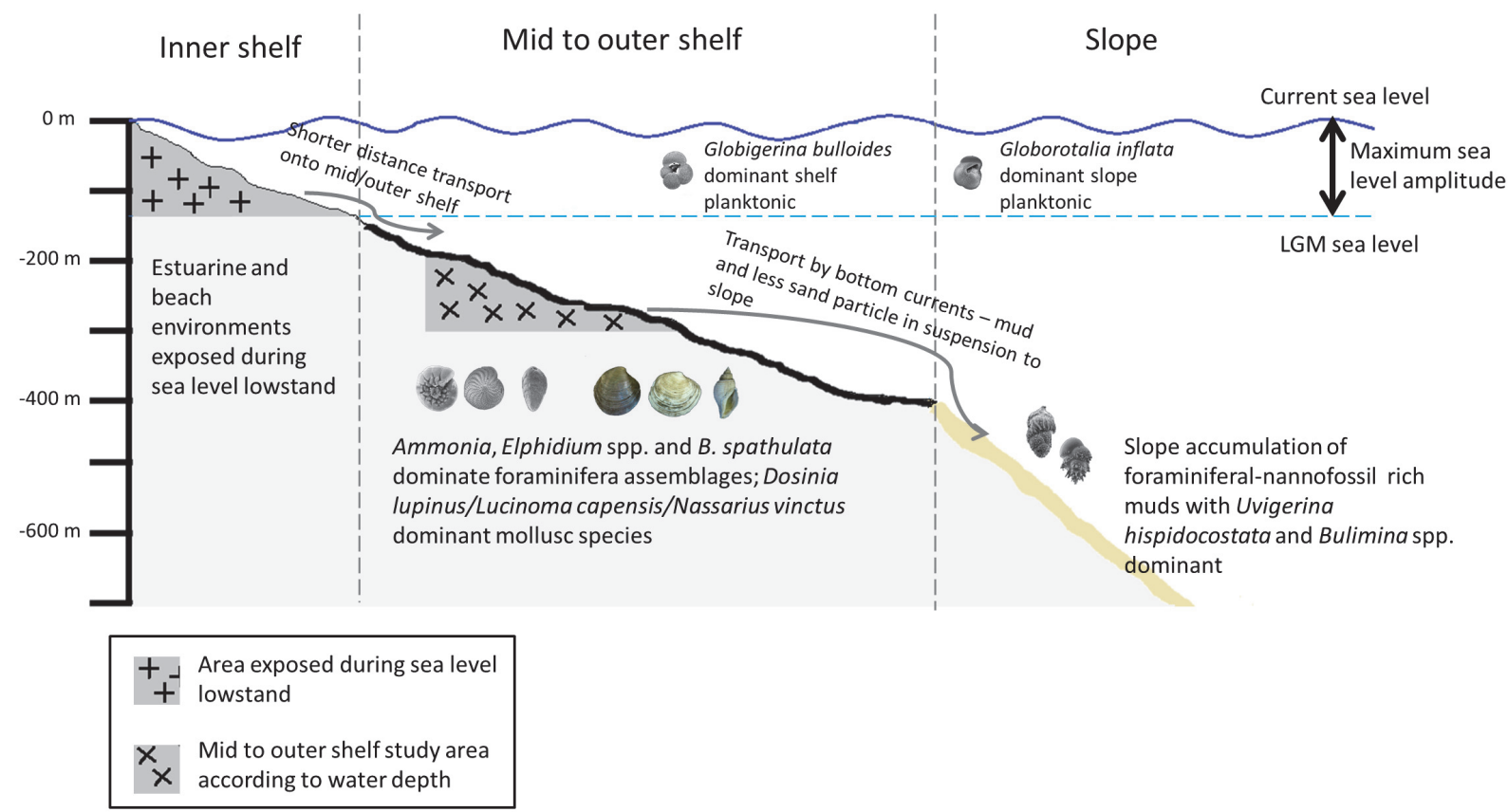

FIGURE 15. Mid to late Pleistocene/Holocene environmental interpretation of the southwestern margin of Africa based on foraminifera and mollusc species found in outer shelf sediments. Slope data and occurrences are based on reports from ODP Leg 175 (Wefer et al., 1998) and results from cores GeoB 20601-4, 8342-6 and 8336-6 (Meteor Cruises M123 and M57/1) in Chapter 7 of Bergh (2019).

turnover is also consistent with cooling periods between 3 and $2 \mathrm{Ma}$ and 1.5 to $0.5 \mathrm{Ma}$ when Namibian sea surface temperatures (SST) decreased by 3 to $5^{\circ} \mathrm{C}$ (Marlow et al., 2000; Lazarus et al., 2006; Etourneau et al., 2009). Marlow et al. (2000) recorded a $10^{\circ} \mathrm{C}$ decline in sea surface temperatures (SST) since $3.2 \mathrm{Ma}$ linked to global cooling and increased upwelling associated with strengthening of southeasterly trade winds (Shi et al., 2001) along the margin.

The Angola-Benguela Front is characterised by Gr. (Gc.) inflata-G. bulloides (Ufkes et al., 1998) and similar assemblages, especially regarding the presence and abundance of G. bulloides. The dominant taxa between these assemblages are the same, but the relative abundances of these taxa and minor taxa vary. Studies with deeper water environments off Central and West Africa (e.g. Ufkes et al., 1998) record a higher number of taxa, but the assemblages also contain the same minor species (Ga. siphonifera, Gs. ruber, Gs. sacculifer, Gr. menardii, Gr. truncatulinoides, Ng. dutertrei, $\mathrm{Ng}$, pachyderma, $\mathrm{Ng}$. incompta, and O. universa) recorded in this study. Relatively high abundances of $G$. bulloides have been reported from other major upwelling regions as well, such as the Arabian Sea (Prell and Curry, 1981; Curry et al., 1992;
Peeters et al., 2002), northwest Africa (Martinez et al., 1999), the eastern margin of South America (Ibaraki, 1997; Marchant et al., 1999; Mohtadi et al., 2005) and California (Sautter and Thunell, 1991). Gr. (Gc.) inflata and G. bulloides are regarded as transitional species (Kucera, 2007), and high relative abundances of $G$. bulloides are also an indicator of strong upwelling conditions (Giraudeau, 1993).

The abundance of warm subtropical to tropical Gs. ruber decreases (Figure 4) during the Pleistocene along the Namibian shelf and Globorotalia menardii and $T$. sacculifer are low in numbers. These warm water species with minor abundances reach the Benguela Region through the inflow of warmer waters from the Angola Current to the north (Kemle-von Mücke and Oberhänsli, 1999) and the transport of low salinity, tropical waters into the Southern Benguela Region from the Agulhas Current (Rau et al., 2002). The high abundance of Orbulina universa, identified as a subtropical species by Kucera (2007), on the northern Namibian shelf during the Pleistocene indicates the influence and proximity of the Angola Current to the north.

The Namibian outer shelf cores indicate Miocene-Pliocene benthic foraminifera (Bergh et al., 2018) being replaced by an Uvigerina spp.-domi- 
nated assemblage during the Pliocene-Pleistocene transition (Compton and Bergh, 2016). The localised faunal turnover during the Pliocene-Pleistocene corresponds with intensification of the BUS (Compton and Bergh, 2016) and the onset of major Northern Hemisphere glaciation, climate cooling and increased glacial cycle amplitudes (Lisiecki and Raymo, 2007).

The three assemblages identified in the Pleistocene units correspond with the three stratigraphic units dated to the early, mid, and late Pleistocene (Figure 6). These changes in assemblage indicate changes in palaeoceanographic conditions, including upwelling intensity, bottom water oxygen and bathymetry related to large sea-level fluctuations, particularly after the mid-Pleistocene transition circa $900 \mathrm{ka}$.

Infaunal foraminifera such as Uvigerina spp. became the dominant taxa in the early Pleistocene when bottom water conditions became more suitable for foraminifera adapted to more eutrophic and dysoxic conditions along the northern Namibian shelf, whereas suboxic indicators were more dominant during the Miocene-Pliocene (Bergh et al., 2018). The benthic species Uvigerina peregrina has been described as a shallow infaunal species adapted to relatively high amounts of organic matter input under variable oxygenated bottom waters more adapted to dysoxic conditions (Fontanier et al., 2002; Koho et al., 2008). Environments with mostly infaunal foraminifera and low diversities are characteristic of eutrophic conditions. Benthic faunal compositions are dependent upon oxygenation and organic detritus, i.e., food supply reaching the ocean floor (e.g., Altenbach and Sarnthein, 1989; Jorissen et al., 1995; Fariduddin and Loubere, 1997; Jorissen et al., 1998). The high relative abundances of Uvigerina spp. are consistent with the occurrences of this taxon in reported eutrophic environments under high organic carbon fluxes typical of upwelling regions such as the BUS (Fontanier et al., 2002; Licari and Mackensen, 2005).

In eutrophic environments the vertical distribution of foraminifera is more dependent on oxygen availability where oxygen concentrations fall below the lower limits of epifaunal taxa. Only deep infaunal taxa adapted to dysoxic conditions will survive below this limit as opposed to oligotrophic environments where more oxygen is consumed at the epifaunal-shallow infaunal level (Jorissen et al., 1995). The results from the Walvis Bay-Lüderitz cores are in agreement with findings by Bergh et al. (2018), which found that the benthic environment changed from oligotrophic conditions prior to the onset of the
BUS in the late Miocene to eutrophic conditions after BUS initiation along the northern Namibian shelf.

Epifaunal abundances increased during the middle Pleistocene (Figure 16). The Mid-Pleistocene Transition (MPT) marks the change in climatic cycles where global ice volume variations shift from being controlled by $41 \mathrm{kyr}$ to $100 \mathrm{kyr}$ cycles (Hays et al., 1976; Pisias and Moore, 1981; Imbrie et al., 1992; Raymo and Nisancioglu, 2003; Elderfield et al., 2012). Sea-level amplitudes increased during the middle Pleistocene dropping by as much as $125 \mathrm{~m}$ (Miller et al., 2005). The study area was closer to the shoreline during sea level lowstands and shallow-water foraminifera $(A$. japonica and $E$. advenum) increased in abundance (Figure 17), which accounts for the observed infaunal-epifaunal ratios found in this study. These taxa indicate estuarine and littoral conditions as evidenced by previous work on foraminifera from the western shelf (McMillan, 1990b; Dale and McMillan, 1998; Dale and McMillan, 1999; Compton et al., 2002, 2004; Franceschini and Compton, 2004; Franceschini et al., 2005; Franceschini and Compton, 2007; Herbert and Compton, 2007) and south coast sediments of South Africa (McMillan, 1990a). The increasing abundance of epifaunal foraminifera along the shelf of Namibia and western South Africa is indicative of environments where a more diverse range of microhabitats are available, e.g., hard and rocky substrates for these foraminifera to attach mixed with softer substrate to burrow into. These shallow water foraminifera were close enough to where the outer shelf is today to be transported into the deeper area during lowered sea levels of glacial maxima (Compton and Wiltshire, 2009).

A comparison between the onshore deposits (Dale and McMillan, 1999) and saltwater marsh foraminifera from southwestern South Africa (Franceschini and Compton, 2004; Franceschini et al., 2005; Franceschini and Compton, 2007) and the outer shelf foraminifera from western South Africa (Compton et al., 2002, 2004) indicate that taxa associated with littoral environments are preserved in onshore deposits and taxa associated with inner shelf environments are preserved in outer shelf sediments off western South Africa. This is consistent with data from this study in which inner shelf species are preserved in outer shelf sediments of Namibia.

The mollusc assemblages across the Namibian shelf indicate similar shallow marine environments. The most abundant mollusc species in unit 


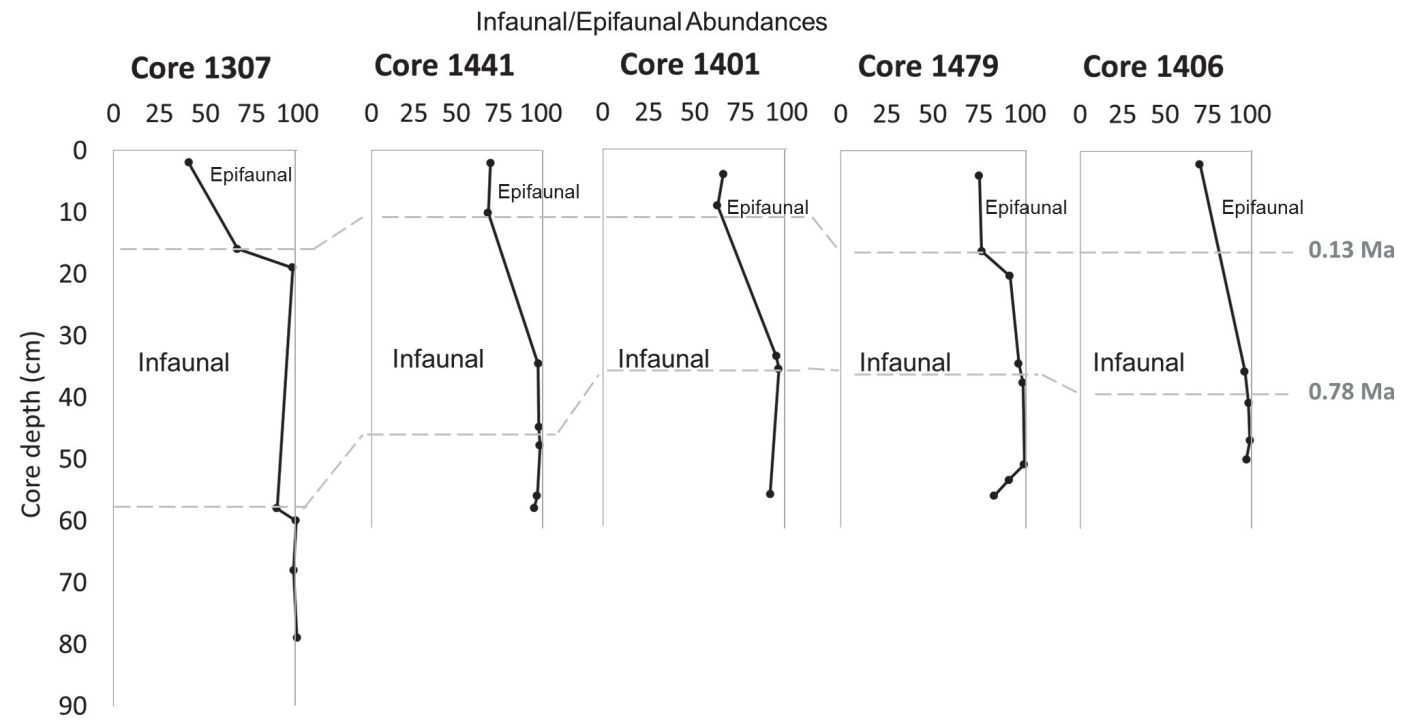

Infaunal/Epifaunal Foraminiferal Species

\section{Core 1307 Core $1441 \quad$ Core $1401 \quad$ Core $1479 \quad$ Core 1406}

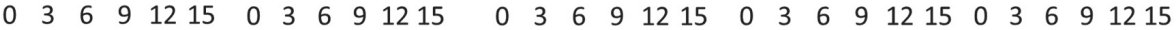

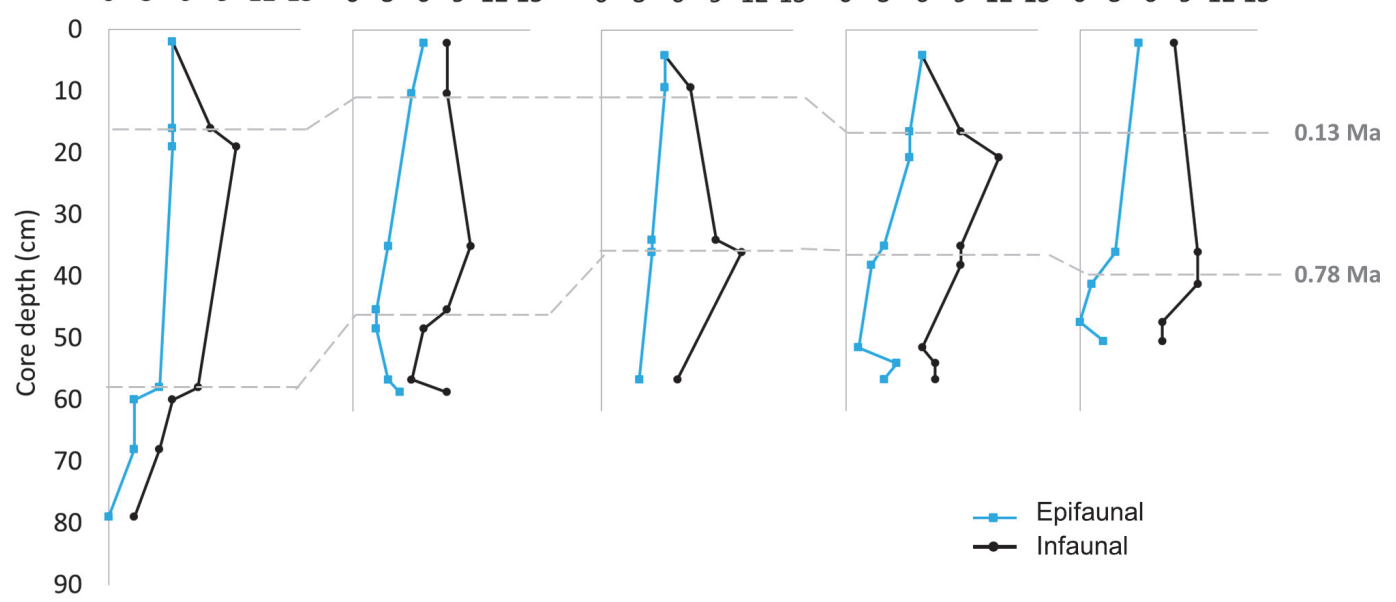

FIGURE 16. Infaunal-epifaunal abundances expressed as relative abundances (\%) and in number of species.

2 of the Walvis Bay-Lüderitz cores, Lucinoma capensis, Turritella declivis, and Comitas saldanhae, occur where B. spathulata and Uvigerina spp. show higher abundances. The dominance of Lucinoma capensis in the shelly sandy units signal organic-rich conditions at the sea floor in the center of upwelling cells (Edelman-Fürstenberg, 2014) and Turritella declivis has been associated with upwelling conditions (Allman, 1988). The occurrence of Turritella declivis indicates water depths of 40 to $220 \mathrm{~m}$ based on present-day occurrences of the species along the south coast of South Africa. Substrate indications based on T. declivis are how- ever broad, as they can occur in thick mud to coarse gravelly sands (Herbert, 2013).

The distribution of molluscs in the BUS (Table 2 ) is influenced by substrate, oxygen content, upwelling conditions, microhabitats, and depth (Edelman-Fürstenberg, 2014; and references therein). Marine transgressions during the late Pleistocene created numerous lagoons, estuaries, and embayments along the coast (Tankard and Rogers, 1978). This accounts for the variability in the mollusc assemblages accumulating in the outer shelf deposits of Namibia and South Africa. During the late Pleistocene to Holocene Dosinia lupinus 


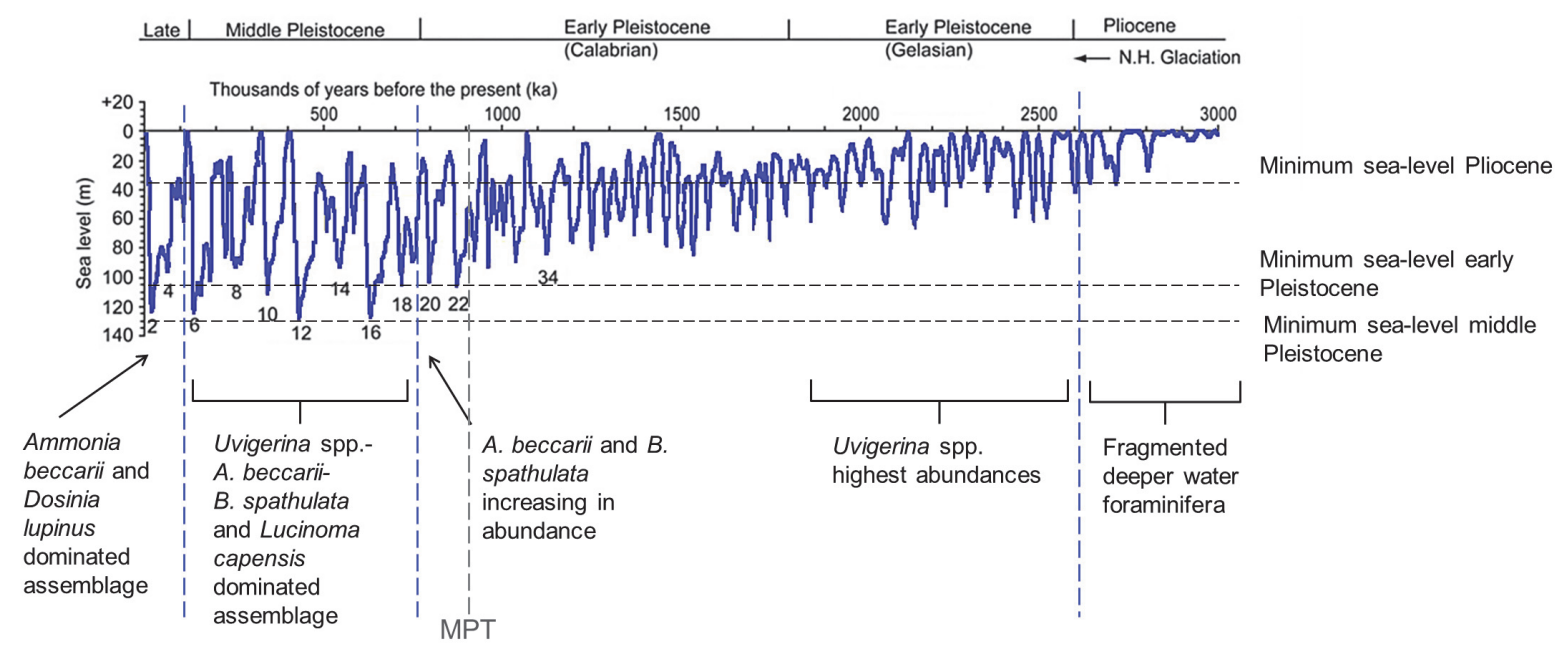

FIGURE 17. Global range in sea level (Bintanja and van de Wal, 2008) since $3 \mathrm{Ma}$ in relation to the foraminiferal and mollusc assemblages preserved in sediments of the study area. MPT = Mid-Pleistocene transition.

TABLE 2. Molluscs recorded in Quaternary cores from the Namibian and northwestern South African shelf.

\begin{tabular}{|c|c|c|c|c|}
\hline Species & Class & $\begin{array}{l}\text { Northern Namibian } \\
\text { shelf (this study) }\end{array}$ & $\begin{array}{l}\text { Walvis Bay-Lüderitz } \\
\text { shelf (this study) }\end{array}$ & $\begin{array}{l}\text { Orange River shelf } \\
\text { Compton et al., 2002) }\end{array}$ \\
\hline Anomia sp. & Bivalvia & $x$ & $x$ & \\
\hline Carditella spp. & Bivalvia & $x$ & $x$ & $x$ \\
\hline Cardium sp. & Bivalvia & $x$ & $x$ & \\
\hline Comitas saldanhae & Bivalvia & $x$ & $x$ & \\
\hline Dosinia lupinus & Bivalvia & $x$ & $x$ & $x$ \\
\hline Hiatella arctica & Bivalvia & $x$ & $x$ & \\
\hline Limopsis chuni & Bivalvia & $x$ & $x$ & \\
\hline Lucinoma capensis & Bivalvia & $x$ & $x$ & $x$ \\
\hline Macomopsis crawfordi & Bivalvia & & & $x$ \\
\hline Marginella spp. & Bivalvia & $x$ & $x$ & \\
\hline Nassarius muiri & Gastropoda & & & $x$ \\
\hline Nassarius plicatellus & Gastropoda & & & $x$ \\
\hline Nassarius vinctus & Gastropoda & $x$ & $x$ & $x$ \\
\hline Nucula nucleus & Bivalvia & $x$ & $x$ & $x$ \\
\hline Nuculana bicuspidata & Bivalvia & $x$ & $x$ & \\
\hline Ostrea spp. & Bivalvia & $x$ & $x$ & \\
\hline Pecten spp. & Bivalvia & $x$ & $x$ & \\
\hline Tellimya trigona & Bivalvia & & & $x$ \\
\hline Tellina analogica & Bivalvia & $x$ & $x$ & $x$ \\
\hline Tivella compressa & Bivalvia & & & $x$ \\
\hline Turritella declivis & Gastropoda & & $x$ & $x$ \\
\hline Venerupis corrugata & Bivalvia & & & $x$ \\
\hline Volutacorbis lutosa & Gastropoda & $\mathrm{x}$ & $\mathrm{x}$ & $\mathrm{x}$ \\
\hline
\end{tabular}


replaced Lucinoma capensis as the dominant bivalve species being preserved in the sediments. During the Holocene off southwest South Africa the dominant bivalve species was also Dosinia lupinus, while Nassarius vinctus and Volutocorbis lutosa are the dominant gastropod species (Compton et al., 2002; Herbert and Compton, 2007). The present-day fauna on the shelf is still composed of abundant Dosinia lupinus (Barnard, 1964; Kilburn and Rippey, 1982). The dominance of the infaunal filter-feeding species Lucinoma capensis and Dosinia lupinus indicates fine grained sedimentation on the shelf (Barnard, 1964; Kensley, 1978; Kilburn and Rippey, 1982), and the turnover of abundant species Dosinia lupinus in unit 1 supports a shoaling marginal marine environment (EdelmanFürstenberg, 2014) of up to $150 \mathrm{~m}$ (Walker et al., 2000), a water depth consistent with the dominance of Ammonia spp. Similar to shallow water foraminifera, Dosinia lupinus is associated with estuarine influences and environments (Branch et al., 2007). Namibian perennial rivers are rare but estuarine influences in the study area could be associated with the Kuiseb River south of Walvis Bay (Watson and Lemon, 1985; Bate, 1993; Meadows, 2001) and the Kunene River (Wearne and Underhill, 2005). Prodelta to delta front sandy and muddy conditions are indicated by the occurrence of the gastropod species Nassarius vinctus in unit 1 at water depths of less than $100 \mathrm{~m}$ when the sea level was up to $125 \mathrm{~m}$ below present-day during the Last Glacial Maximum (LGM) (Miller et al., 2005). The good preservation of the shells, and in places articulated valves, indicate minimal disturbance, consistent with lowered sea level during the LGM and the accumulation of abundant Dosinia valves in the uppermost unit of the cores. Alternatively, the autochthonous deposition of articulated valves could also be explained during sea level rise, descending wave and current energy and rapid sediment burial which would cause minimal disturbance, as shown for example in the Orange River prodelta (Compton et al., 2002).

\section{CONCLUSIONS}

Upwelling indicator species and transitional planktic species along the Namibian margin appear in Pliocene-Pleistocene sediments, which are associated with the initiation of the BUS during the late Miocene to Pliocene. The present-day assemblages and foraminifera on the shelf in surface grab samples from previous studies can be traced back in vibracores from the shelf to the Pleistocene during a period in which the BUS intensified. The major planktic species is interpreted to be controlled by the cold upwelled waters. The planktic foraminifera are dominated by transitional to cold water species with minor occurrences of warm water species Globigerinoides ruber, Globorotalia menardii, Trilobatus sacculifer, and Orbulina universa. The minor occurrences of warm water species are attributed to the inflow of warm currents from the north (Angola Current) and south (Agulhas Current) of the BUS and the high abundances of Orbulina universa on the northern Namibian shelf to the proximity of the Angola Current.

The wide distribution of the major benthic foraminiferal taxa stretching across the BUS and into the south and east coasts of South Africa are controlled by the microhabitat which, in turn, is influenced by substrate, organic matter fluxes and dissolved bottom water oxygen contents. Only a few species, such as Hyalinea balthica, Quinqueloculina seminula, Cassidulina laevigata, and Bulimina marginata recorded from the outer shelf are recorded in trace to minor amounts on the slope. Apart from some taxa, such as Cassidulina spp. and Bulimina spp., having broad bathymetric ranges, there is minimal transport from the shelf to slope as energy dispersion is too weak and the shelf too broad to suspend and transport sandsized components, such as foraminifera.

A palaeoenvironmental shift from relatively deep to shallow depths is recorded in Pleistocene sediments along the southwestern shelf of southern Africa. The Miocene-Pliocene to PliocenePleistocene marks a period in which oceanographic and climate changes led to the turnover of foraminiferal assemblages along the southwestern margin of Africa from a warm subtropical assemblage to colder, shallow water assemblages. The shift in the palaeo-environment during the Pleistocene was most noticeable in the Walvis BayLüderitz region where outer shelf sediments reveal an Uvigerina spp.-dominated assemblage in the lower Pleistocene. The Uvigerina spp.-assemblage indicates eutrophic conditions under high organic carbon conditions. During the MPT, Uvigerina spp. relative abundances decrease and epifaunal foraminifera increase indicating slightly less eutrophic conditions. This assemblage occurs together with the mollusc species Lucinoma capensis, Turritella declivis, and Comitas saldanhae, which indicate increased upwelling conditions. During the upper Pleistocene an Ammonia japonica-assemblage is established and the dominance of the Lucinoma capensis bivalve species replaced by Dosinia lupinus indicating mostly taxa adapted to suboxic con- 
ditions with increased epifaunal abundances in marginal marine to inner shelf environments.

The upper Pleistocene to Holocene foraminifera and molluscs are recorded in a wide range of depositional settings along the shelf of southern Africa, which include the outer shelf, the mudbelt on the inner shelf, estuarine, lagoonal and beach environments. Their high relative abundance in the uppermost sections of the cores indicates a strong influence of estuarine, lagoonal and beach environments on the middle to outer shelf sediments.

The foraminifera and mollusc assemblages indicate that the palaeoenvironment of the area was shoaling during the Pleistocene, especially when compared to the Miocene-Pliocene assemblages, and is consistent with higher amplitude sea-level fluctuations, particularly sea-level low- stands of as much as $125 \mathrm{~m}$ below present sea level after the Mid-Pleistocene Transition. The water depth thus lowered from a deep outer shelf environment in the middle Miocene to early Pliocene to palaeodepths fluctuating between the inner and middle shelf during the Pleistocene.

\section{ACKNOWLEDGEMENTS}

Comments and suggestions to the manuscript were provided by P. Frenzel, G. Schmiedl, M. Kaminski, M. Kucera, H. Filipsson, and an anonymous reviewer. The cores were provided by Minemakers Pty. Ltd. Melissa Oosthuizen assisted in the laboratory with processing of some of the Northern Namibian core material.

\section{REFERENCES}

Adams, A. and Reeve, L. 1848-50. Mollusca, pp. 1-24 (1848), 25-87 (1850). In Adams, A. (ed.), The Zoology of the Voyage of HMS Samarang: Under the Command of Captain Sir Edward Belcher, C.B., F.R.A.S., F.G.S. During the Years 1843-46. Reeve, Benham and Reeve, London.

Allman, W.D. 1988. Ecology of the Recent turritelline gastropods (Prosobranchia, Turritellidae): current knowledge and paleontological implications. Palaios, 3:259-284. https://doi.org/ $10.2307 / 3514657$

Altenbach, A.V. and Sarnthein, M. 1989. Productivity record in benthic foraminifera, p. 255-269. In Berger, W.H., Smetacek, V.S. and Wefer, G. (eds.). Productivity of the Ocean: Present and Past. Wiley, New York.

Barnard, K. H. 1958. Contributions to the knowledge of South African marine molluscs. Part I. Gastropoda: Prosobranchiata: Toxoglossa. Annals of the South African Museum, 44:73-163.

Barnard, K. H. 1964. Contributions to the knowledge of South African marine molluscs. Part V. Lamellibranchiata. Annals of the South African Museum, 47:361-593

Bate, B.H. 1993. Water relations of the vegetation along the Kuiseb River, Namibia. Madoqua, 18(2):85-91.

Baumann, K.H. and Freitag, T. 2004. Pleistocene fluctuations in the northern Benguela Current system as revealed by coccolith assemblages. Marine Micropaleontology, 52:195-215. https:/ /doi.org/10.1016/j.marmicro.2004.04.011

Berger, W.H., Wefer, G., Richter, C., Lange, C.B., Giraudeau, J., Hermelin, O., and Shipboard Scientific Party. 1998. The Angola-Benguela Upwelling System: Paleoceanographic synthesis of shipboard results from Leg 175. Proceedings of the Ocean Drilling Program, Initial Reports, 175:505-531. https://doi.org/10.2973/odp.proc.ir.175.117.1998

Bergh, E.W. 2019. Neogene to Quaternary Foraminifera from the Southwestern Margin of Southern Africa. Unpublished PhD Thesis, University of Cape Town, Cape Town, South Africa.

Bergh, E.W., Compton, J.S., and Frenzel, P. 2018. Late Neogene foraminifera from the northern Namibian continental shelf and the transition to the Benguela Upwelling System. Journal of African Earth Sciences, 141:33-48. https://doi.org/10.1016/j.jafrearsci.2018.01.018

Bintanja, R. and van de Wal, R.S.W. 2008. North American ice-sheet dynamics and the onset of 100,000-year glacial cycles. Nature, 454:869-872. https://doi.org/10.1038/nature07158

Bolli, H.M., Saunders, J.B., and Perch-Nielsen, K. 1985. Plankton Stratigraphy. Cambridge University Press, Cambridge. 
Brady, H.B. 1877. Supplementary note on the foraminifera of the chalk (?) of the New Britain Group. Geological Magazine, 4:534-536. https://doi.org/10.1017/s0016756800150137

Branch, G.M., Griffiths, C.L., Branch, M.L., and Beckley, L.E. 2007. Two Oceans: A Guide to the Marine Life of Southern Africa. Penguin Random House, South Africa.

Bremner, J.M. 1977. Sediments on the Continental Margin off South West Africa between Sylvia Hill and the Kunene River. Unpublished PhD Thesis, University of Cape Town, Cape Town, South Africa.

Cifelli, R. 1961. Globigerina incompta, a new species of pelagic foraminifera from the North Atlantic. Contributions from the Cushman Foundation for Foraminiferal Research, 12:83-86. https://doi.org/10.2113/gsjfr.3.4.157

Compton, J.S. and Bergh, E.W. 2016. Phosphorite deposits on the Namibian shelf. Marine Geology, 380:290-314. https://doi.org/10.1016/j.margeo.2016.04.006

Compton, J.S., Mulabisana, J., and McMillan, I.K. 2002. Origin and age of phosphorite from the Last Glacial Maximum to Holocene transgressive succession off the Orange River, South Africa. Marine Geology, 186(3-4):43-261. https://doi.org/10.1016/s0025-3227(02)00211-6

Compton, J.S., Wigley, R., and McMillan, I.K. 2004. Late Cenozoic phosphogenesis on the western shelf of South Africa in the vicinity of the Cape Canyon. Marine Geology, 206:19-40. https://doi.org/10.1016/j.margeo.2004.02.004

Compton, J.S. and Wiltshire, J.G. 2009. Terrigenous sediment export from the western margin of South Africa on glacial to interglacial cycles. Marine Geology, 266:212-222. https://doi.org/ 10.1016/j.margeo.2009.08.013

Curry, W.B., Ostermann, D.R., Guptha, M.V.S., and Ittekkot, V. 1992. Foraminiferal production and monsoonal upwelling in the Arabian Sea: evidence from sediment traps. Geological Society, London, Special Publications, 64:93-106. https://doi.org/10.1144/ gsl.sp.1992.064.01.06

d'Orbigny, A.D. 1826. Tableau méthodique de la classe des Céphalopodes. Annales des Sciences Naturelles, 7:245-314.

d'Orbigny, A.D. 1839a. Foraminifères, p. 1-224. In de la Sagra, R. (ed.), Histoire physique, Politique et Naturelle de l'ile de Cuba. A. Bertrand, Paris.

d'Orbigny, A. D. 1839b. Les foraminifères des îles Canaries, p. 119-146. In Barker-Webb, P. and Berthelot, S. (eds.), Histoire Naturelle des lles Canaries vol. 2.

d'Orbigny, A.D. 1846. Foraminiferes Fossiles du Basin Tertiaire de Vienne (Austriche). Gide et Comp, Paris.

Dale, D.C. and McMillan, I.K. 1998. Mud belt and middle shelf benthonic and planktonic foraminiferal assemblages and sedimentation processes compared through the Holocene successions at two tropical African (Sierra Leone) and two temperate African (western offshore, South Africa) sites. South African Journal of Science, 94:319-340.

Dale, D.C. and McMillan, I.K. 1999. On the Beach: A Field Guide to the Late Cainozoic Micropalaeontological History, Saldanha Region, South Africa. Earthyear Environmental Communications.

Diester-Haass, L., Meyers, P.A., and Rothe, P. 1992. The Benguela Current and associated upwelling on the southwest African Margin: a synthesis of the Neogene-Quaternary sedimentary record at DSDP sites 362 and 532. Geological Society, London, Special Publications, 64:331-342. https://doi.org/10.1144/gsl.sp.1992.064.01.22

Diester-Haass, L. and Rothe, P. 1987. Plio-Pleistocene sedimentation on the Walvis Ridge, southeast Atlantic (DSDP Leg 75, Site 532)_influence of surface currents, carbonate dissolution and climate. Marine Geology, 77:53-85. https://doi.org/10.1016/00253227(87)90083-1

Dingle, R.V., Siesser, W.G., and Newton, A.R. 1983. Mesozoic and Tertiary Geology of Southern Africa. A.A. Balkema, Rotterdam.

Edelman-Furstenberg, Y. 2014. Distribution and paleoecology of molluscan skeletal remains along an upwelling tract: Benguela system, Namibian shelf. Marine Geology, 353:153-162. https://doi.org/10.1016/j.margeo.2014.04.011

Elderfield, H., Ferretti, P., Greaves, M., Crowhurst, S., McCave, I.N., Hodell, D., and Piotrowski, A.M. 2012. Evolution of ocean temperature and ice volume through the mid-Pleistocene climate transition. Science, 337:704-709. https://doi.org/10.1126/science.1221294

Etourneau, J., Martinez, P., Blanz, T., and Schneider, R. 2009. Pliocene-Pleistocene variability of upwelling activity, productivity, and nutrient cycling in the Benguela region. Geology, 37:871874. https://doi.org/10.1130/g25733a.1 
Fariduddin, M. and Loubere, P. 1997. The surface ocean productivity response of deeper water benthic foraminifera in the Atlantic Ocean. Marine Micropaleontology, 32:289-310. https:// doi.org/10.1016/s0377-8398(97)00026-1

Fontanier, C., Jorissen, F.J., Licari, L., Alexandre, A., Anschutz, P., and Carbonel, P. 2002. Live benthic foraminiferal faunas from the Bay of Biscay: faunal density, composition, and microhabitats. Deep Sea Research Part I: Oceanographic Research Papers, 49:751-785. https://doi.org/10.1016/s0967-0637(01)00078-4

Franceschini, G. and Compton, J.S. 2004. Aeolian and marine deposits of the Tabakbaai Quarry area, Western Cape, South Africa. South African Journal of Geology, 107:619-632. https:// doi.org/10.2113/gssajg.107.4.619

Franceschini, G. and Compton, J.S. 2007. Abrasion of foraminifera tests along an active dune cordon, Western Cape, South Africa. Palaios, 22:686-690. https://doi.org/10.2110/ palo.2006.p06-102r

Franceschini, G., McMillan, I.K., and Compton, J.S. 2005. Foraminifera of Langebaan Lagoon salt marsh and their application to the interpretation of late Pleistocene depositional environments at Monwabisi, False Bay coast, South Africa. South African Journal of Geology, 108:285-296. https://doi.org/10.2113/108.2.285

Giraudeau, J. 1993. Planktonic foraminiferal assemblages in surface sediments from the southwest African continental margin. Marine Geology, 110:47-62. https://doi.org/10.1016/ 0025-3227(93)90104-4

Hammer, Ø., Harper, D.A.T., and Ryan, P.D. 2001. PAST: paleontological statistics software package for education and data analysis. Palaeontologia Electronica, 4.1.4:1-9. http://palaeo-electronica.org/2001_1/past/issue1_01.htm

Hay, W.W., Sibuet, J.C., Barron, E.J., Brassell, S.C., Dean, W.E., Huc, A.Y., Keating, B.H., McNulty, C.L., Meyers, P.A., Nohara, M., Schallreuter, R.E.L., Steinmetz, J.C., Stow, D.A.V., Stradner, H., Boyce, R.E., and Amidei, R. 1984. Initial Reports of the Deep Sea Drilling Project, volume 75. U.S. Government Printing Office, Washington, D.C. https://doi.org/ 10.2973/dsdp.proc.75.1984

Hays, J., Imbrie, J., and Shackleton, N. 1976. Variations in the earth's orbit: pacemaker of the ice ages. Science, 194:1121-1132. https://doi.org/10.1126/science.194.4270.1121

Herbert, C.T. and Compton, J.S. 2007. Geochronology of Holocene sediments on the western margin of South Africa. South African Journal of Geology, 110:327-338. https://doi.org/ 10.2113/gssajg.110.2-3.327

Herbert, D.G. 2013. Turritella declivis Adams \& Reeve, in Reeve, 1849 (Mollusca: Gastropoda)— a South African not an Australian species, and a characteristic component of the Agulhas Bank benthos. African Zoology, 48:412-417. https://doi.org/10.1080/ 15627020.2013.11407611

Ibaraki, M. 1997. Closing of the Central American Seaway and Neogene coastal upwelling along the Pacific coast of South America. Tectonophysics, 281:99-104. https://doi.org/10.1016/ s0040-1951(97)00161-3

Imbrie, J., Boyle, E.A., Clemens, S.C., Duffy, A., Howard, W.R., Kukla, G., Kutzbach, J., Martinson, D.G., Mclntyre, A., Mix, A.C., Molfino, B., Morley, J.J., Peterson, L.C., Pisias, N.G., Prell, W.L., Raymo, M.E., Shackleton, N.J., and Toggweiler, J.R. 1992. On the structure and origin of major glaciation cycles 1 . Linear responses to Milankovitch. forcing. Paleoceanography, 7:701-738. https://doi.org/10.1029/92pa02253

Jaeckel, S. and Thiele, J. 1931. Muscheln der Deutschen Tiefsee Expedition. Wissenschaftliche Ergebnisse der Deutschen Tiefsee-Expedition auf dem Dampfer “Valdivia” 1898-1899, 21:161-268.

Jahn, B., Donner, B., Müller, P.J., Röhl, U., Schneider, R.R., and Wefer, G. 2003. Pleistocene variations in dust input and marine productivity in the northern Benguela Current: evidence of evolution of global glacial-interglacial cycles. Palaeogeography, Palaeoclimatology, Palaeoecology, 193:515-533. https://doi.org/10.1016/s0031-0182(03)00264-5

Jorissen, F.J., de Stigter, H.C., and Widmark, J.G. 1995. A conceptual model explaining benthic foraminiferal microhabitats. Marine Micropaleontology, 26:3-15. https://doi.org/10.1016/03778398(95)00047-x

Jorissen, F.J., Wittling, I., Peypouquet, J.P., Rabouille, C., and Relexans, J.C. 1998. Live benthic foraminiferal faunas off Cap Blanc, NW Africa: community structure and microhabitats. DeepSea Research I, 45:2157-2188. https://doi.org/10.1016/s0967-0637(98)00056-9 
Kemle-von Mücke, S. and Oberhänsli, H. 1999. The distribution of living planktic foraminifera in relation to southeast Atlantic oceanography, p. 91-115. In Use of Proxies in Paleoceanography. Springer, Berlin-Heidelberg.

Kennett, J.P. and Srinivasan, M.S. 1983. Neogene Planktonic Foraminifera. A Phylogenetic Atlas. Hutchinson Ross, Stroudsburg

Kensley, B. 1978. Interaction between coastal processes and lagoonal fauna, between Walvis Bay and Lüderitzbucht, South West Africa. Madoqua, 11:55-60.

Kilburn, R. and Rippey, E. 1982. Sea Shells of Southern Africa. Macmillan South Africa, Johannesburg.

Koho, K.A., García, R., De Stigter, H.C., Epping, E., Koning, E., Kouwenhoven, T.J., and Van der Zwaan, G.J. 2008. Sedimentary labile organic carbon and pore water redox control on species distribution of benthic foraminifera: A case study from Lisbon-Setúbal Canyon (southern Portugal). Progress in Oceanography, 79(1):55-82. https://doi.org/10.1016/ j.pocean.2008.07.004

Kucera, M. 2007. Planktonic foraminifera as tracers of past oceanic conditions, p. 213-262. In Hillaire-Marcel, C. and de Vernal, A. (eds.), Proxies in Late Cenozoic Paleoceanography. Elsevier, Amsterdam. https://doi.org/10.1016/s1572-5480(07)01011-1

Lazarus, D., Bittniok, B., Diester-Haass, L., Billups, K., Ogawa, Y., Takahashi, K., and Meyers, P. 2008. Radiolarian and sedimentologic paleoproductivity proxies in late Pleistocene sediments of the Benguela Upwelling System, ODP Site 1084. Marine Micropaleontology, 68:223-235. https://doi.org/10.1016/j.marmicro.2008.02.004

Lazarus, D., Bittniok, B., Diester-Haass, L., Meyers, P., and Billups, K. 2006. Comparison of radiolarian and sedimentologic paleoproductivity proxies in the latest Miocene-Recent Benguela Upwelling System. Marine Micropaleontology, 60:269-294. https://doi.org/10.1016/ j.marmicro.2006.06.003

Leiter, C. and Altenbach, A.V. 2010. Benthic foraminifera from the diatomaceous mud belt off Namibia: characteristic species for severe anoxia. Palaeontologia Electronica, 13.2.11A:119. https://palaeo-electronica.org/2010_2/188/index.html

Licari, L. and Mackensen, A. 2005. Benthic foraminifera off west Africa ( $1^{\circ} \mathrm{N}$ to $\left.32^{\circ} \mathrm{S}\right)$ : Do live assemblages from the topmost sediment reliably record environmental variability? Marine Micropaleontology, 55:205-233. https://doi.org/10.1016/j.marmicro.2005.03.001

Linnaeus, C. 1758. Systema Naturae per Regna Tria Naturae [editio decima, reformata 1 (Regnum animale)]. Salvii, Stockholm, pp. 824. https://doi.org/10.5962/bhl.title.542

Lisiecki, L.E. and Raymo, M.E. 2007. Plio-Pleistocene climate evolution: trends and transitions in glacial cycle dynamics. Quaternary Science Reviews, 26:56-69. https://doi.org/10.1016/ j.quascirev.2006.09.005

Lowry, F.M.D. 1987. Foraminiferal Thanatocoenoses from the Continental Shelf of Southern Africa. Unpublished PhD Thesis, University College London, United Kingdom.

Lutjeharms, J.R.E. and Stockton, P.L. 1987. Kinematics of the upwelling front off Southern Africa. South African Journal of Marine Science 5:35-49. https://doi.org/10.2989/ 025776187784522612

Marchant, M., Hebbeln, D., and Wefer, G. 1999. High resolution planktic foraminiferal record of the last 13,300 years from the upwelling area off Chile. Marine Geology, 161:115-128. https:/ /doi.org/10.1016/s0025-3227(99)00041-9

Marlow, J.R., Lange, C.B., Wefer, G., and Rosell-Mele, A. 2000. Upwelling intensification as part of the Pliocene-Pleistocene climate transition. Science, 290:2288-2291. https://doi.org/ 10.1126/science.290.5500.2288

Marrat, F.P. 1877. On forty proposed new forms in the genus Nassa. Meek, Thomas \& Co. "St George's" Printing Works, Liverpool.

Martin, R.A. 1974. Benthonic foraminifera from the western coast of southern Africa. Bulletin Joint Geological Survey of South Africa/ University of Cape Town Marine Geology Programme Technical Report, 6:83-87.

Martin, R.A. 1981. Benthic foraminifera from the Orange-Lüderitz shelf southern African continental margin. Bulletin Joint Geological Survey of South Africa/ University of Cape Town Marine Geoscience Unit, 11:1-75.

Martinez, P., Bertrand, P., Shimmield, G.B., Cochrane, K., Jorissen, F.J., Foster, J., and Dignan, M. 1999. Upwelling intensity and ocean productivity changes off Cape Blanc (northwest Africa) during the last 70,000 years: geochemical and micropalaeontological evidence. Marine Geology, 158:57-74. https://doi.org/10.1016/s0025-3227(98)00161-3 
McMillan, I.K. 1987. Late Quaternary Foraminifera from the Southern Part of Offshore South West Africa/Namibia. Unpublished PhD Thesis, University of Wales, Aberystwyth, Wales.

McMillan, I.K. 1990a. A foraminiferal biostratigraphy and chronostratigraphy for the Pliocene to Pleistocene Upper Algoa Group, Eastern Cape, South Africa. South African Journal of Geology, 93:622-644.

McMillan, I.K. 1990b. Foraminifera from the Late Pleistocene (latest Eemian to earliest Weichselian) shelly sands of Cape Town city centre, South Africa. Annals of the South African Museum, 99:121-186.

Meadows, M.E. 2001. The role of Quaternary environmental change in the evolution of landscapes: case studies from southern Africa. Catena, 42(1):39-57. https://doi.org/10.1016/ s0341-8162(00)00115-6

Meyers, P.A., Berger, W.H., Wefer, G., Adams, D., Anderson, L., Andreasen, D., Bruchert, V., Cambray, H., Christensen, B., Frost, G., Giraudeaeu, J., Gorgas, T., Hermelin, O., Jansen, F., Lange, C.B., Laser, B., Lin, H-L., Maslin, M.A., Meyers, P., Motoyama, I., Murray, R., Perez, M.E., Pufahl, P., Richter, C., Spiess, V., Vidal, L., Wigley, R., and Yamazaki, T. 1998. Microbial gases in sediments from the southwest African margin, p. 555-560. In Wefer, G., Berger, W.H., Richter, C. et al. (eds.), Proceedings of the Ocean Drilling Program. Initial Reports 175. Ocean Drilling Program, College Station, Texas. https://doi.org/10.2973/ odp.proc.ir.175.121.1998

Miller, K.G., Kominz, M.A., Browning, J.V., Wright, J.D., Mountain, G.S., Katz, M.E., Sugarman, P.J., Cramer, B.S., Christie-Blick, N., and Pekar, S.F. 2005. The Phanerozoic record of global sea-level change. Science, 310:1293-1298. https://doi.org/10.1126/science.1116412

Mohtadi, M., Hebbeln, D., and Marchant, M. 2005. Upwelling and productivity along the PeruChile Current derived from faunal and isotopic compositions of planktic foraminifera in surface sediments. Marine Geology, 216:107-126. https://doi.org/10.1016/ j.margeo.2005.01.008

Mollenhauer, G., Schneider, R.R., Müller, P.J., Spieß, V., and Wefer, G. 2002. Glacial/interglacial variability in the Benguela upwelling system: Spatial distribution and budgets of organic carbon accumulation. Global Biogeochemical Cycles, 16(4):1134. https://doi.org/10.1029/ $2001 \mathrm{gb001488}$

Moroshkin, K.V., Bubnov, V.A., and Bulatov, R.P. 1970. Water circulation in the Eastern South Atlantic Ocean. Oceanology, 10:27-37.

Parker W.K., Jones T.R., and Brady H. B. 1865. On the nomenclature of the Foraminifera. Part $X$. (continued). The species enumerated by D'Orbigny in the 'Annales des Sciences Naturelles,' 1826, vol. vii. - III. The species illustrated by models. Annals and Magazine of Natural History, 16(91):15-41.

Pedersen, T.F. and Calvert, S.E. 1990. Anoxia vs. productivity: what controls the formation of organic-carbon-rich sediments and sedimentary Rocks? AAPG Bulletin, 74(4):454-466.

Peeters, F.J., Brummer, G.J.A., and Ganssen, G. 2002. The effect of upwelling on the distribution and stable isotope composition of Globigerina bulloides and Globigerinoides ruber (planktic foraminifera) in modern surface waters of the NW Arabian Sea. Global and Planetary Change, 34:269-291. https://doi.org/10.1016/s0921-8181(02)00120-0

Pisias, N.G. and Moore, T.C. 1981. The evolution of Pleistocene climate: a time series approach. Earth and Planetary Science Letters, 52:450-458. https://doi.org/10.1016/0012821x(81)90197-7

Prell, W.L. and Curry, W.B. 1981. Faunal and isotopic indices of monsoonal upwelling-western Arabian Sea. Oceanologica Acta, 4:91-98.

Rau, A.J., Rogers, J., Lutjeharms, J.R.E., Giraudeau, J., Lee-Thorp, J.A., Chen, M.T., and Waelbroeck, C. 2002. A 450-kyr record of hydrological conditions on the western Agulhas Bank Slope, south of Africa. Marine Geology, 180:183-201. https://doi.org/10.1016/s00253227(01)00213-4

Raymo, M.E. and Nisancioglu, K.H. 2003. The 41 kyr world: Milankovitch's other unsolved mystery. Paleoceanography, 18(1):1011. https://doi.org/10.1029/2002pa000791

Robinson, R.S., Meyers, P.A., and Murray, R.W. 2002. Geochemical evidence for variations in delivery and deposition of sediment in Pleistocene light-dark color cycles under the Benguela Current Upwelling System. Marine Geology, 180:249-270. https://doi.org/10.1016/ s0025-3227(01)00217-1

Rogers, J. 1977. Sedimentation on the Continental Margin Off the Orange River and the Namib Desert. Unpublished PhD Thesis, University of Cape Town, Cape Town, South Africa. 
Sautter, L.R. and Thunell, R.C. 1991. Seasonal variability in the $\delta^{18} \mathrm{O}$ and $\delta^{13} \mathrm{C}$ of planktonic foraminifera from an upwelling environment: sediment trap results from the San Pedro Basin, Southern California Bight. Paleoceanography, 6:307-334. https://doi.org/10.1029/91pa00385

Schmidt-Sinns, J. 2008. Rezente Benthische Foraminiferen im Bereich des Benguelastroms, Südwestafrika-Verbreitungsmuster und Ihre Steuernden Faktoren. Unpublished PhD Thesis, Universitätsund Landesbibliothek, Bonn, Germany.

Schmiedl, G. 1995. Rekonstruktion der spätquartären Tiefenwasserzirkulation und Produktivität im östlichen Südatlantik anhand von benthischen Foraminiferenvergesellschaftungen / Late Quaternary benthic foraminiferal assemblages from the eastern South Atlantic Ocean: reconstruction of deep water circulation and productivity changes. Berichte zur Polarforschung (Reports on Polar Research), vol. 160, Alfred Wegener Institut für Polar und Meeresforschung, Bremerhaven.

Schmiedl, G. and Mackensen, A. 1997. Late Quaternary paleoproductivity and deep water circulation in the eastern South Atlantic Ocean: evidence from benthic foraminifera. Palaeogeography, Palaeoclimatology, Palaeoecology, 130:43-80. https://doi.org/10.1016/ s0031-0182(96)00137-x

Schmiedl, G., Mackensen, A., and Müller, P.J. 1997. Recent benthic foraminifera from the eastern South Atlantic Ocean: dependence on food supply and water masses. Marine Micropaleontology, 32:249-287. https://doi.org/10.1016/s0377-8398(97)00023-6

Shannon, L.V. and Nelson, G. 1996. The Benguela: large scale features and processes and system variability, p. 163-210. In Wefer, G., Berger, W.H., Siedler, G., and Webb, D. (eds.), The South Atlantic: Present and Past Circulation. Springer Verlag, Heidelberg. https://doi.org/ 10.1007/978-3-642-80353-6_9

Shi, N., Schneider, R., Beug, H.J., and Dupont, L.M. 2001. Southeast trade wind variations during the last $135 \mathrm{kyr}$ : evidence from pollen spectra in eastern South Atlantic sediments. Earth and Planetary Science Letters, 187:311-321. https://doi.org/10.1016/s0012821x(01)00267-9

Sowerby, G.B. III. 1904. Mollusca of South Africa. (Pelecypoda.). Marine Investigations in South Africa, 4:1-19.

Tankard, A.J. and Rogers, J. 1978. Late Cenozoic palaeoenvironments on the west coast of southern Africa. Journal of Biogeography, 5:319-337. https://doi.org/10.2307/3038026

Ufkes, E., Jansen, G.H.F., and Brumrner, G-J.A. 1998. Living planktonic foraminifera in the eastern South Atlantic during spring: indicators of water masses, upwelling and the Congo (Zaire) River plume. Marine Micropaleontology, 33:27-53. https://doi.org/10.1016/s03778398(97)00032-7

Walker, S.T., Mantle, D., Bythell, J.C., and Thomason, J.C. 2000. Oxidative-stress: comparison of species specific and tissue specific effects in the marine bivalves Mytilus edulis (L.) and Dosinia lupinus (L.). Comparative Biochemistry and Physiology Part B: Biochemistry and Molecular Biology, 127:347-355. https://doi.org/10.1016/s0305-0491(00)00266-2

Watson, I. and Lemon, R.R. 1985. Geomorphology of a coastal desert: The Namib, South West Africa/Namibia. Journal of Coastal Research, 1(4):329-342.

Wearne, K. and Underhill, L.G. 2005. Walvis Bay, Namibia: a key wetland for waders and other coastal birds in southern Africa. Bulletin-wader Study Group, 107:24.

Wefer, G., Berger, W.H., Richter, C., Adams, D.D., Anderon, L.D., Andreasen, D.J., Brüchert, V., Cambray, H., Christensen, B.A., Frost, G.M., Giraudeau., Gorgas, T.J., Hermelin, O., Lange, C.B., Laser, B., Lin, H-L., Maslin, M., Meyers, P.A., Motoyama, I., Murray, R.W., Pato, D., Perez, M.E., Pufahl, P.K., Spiess, V., Vidal. L., Wigley, R., and Yamazaki, T. 1998. Proceedings of the Ocean Drilling Program, Initial Reports 175, Ocean Drilling Program, College Station, Texas. https://doi.org/10.2973/odp.proc.ir.175.1998

Wigley, R.A. and Compton, J.S. 2006. Late Cenozoic evolution of the outer continental shelf at the head of the Cape Canyon, South Africa. Marine Geology, 226:1-23. https://doi.org/ 10.1016/j.margeo.2005.09.015 